archives-ouvertes

\title{
Oxadiazolone derivatives, new promising multi-target inhibitors against $M$. tuberculosis
}

Phuong Chi Nguyen, Vincent Delorme, Anaiis Benarouche, Alexandre Guy,

Valérie Landry, Stéphane Audebert, Matthieu Pophillat, Luc Camoin, Céline

Crauste, Jean-Marie Galano, et al.

\section{To cite this version:}

Phuong Chi Nguyen, Vincent Delorme, Anaïs Benarouche, Alexandre Guy, Valérie Landry, et al.. Oxadiazolone derivatives, new promising multi-target inhibitors against M. tuberculosis. Bioorganic Chemistry, 2018, 81, pp.414-424. <10.1016/j.bioorg.2018.08.025>. <hal-01875577>

\section{HAL Id: hal-01875577 \\ https://hal-amu.archives-ouvertes.fr/hal-01875577}

Submitted on 16 Oct 2018

HAL is a multi-disciplinary open access archive for the deposit and dissemination of scientific research documents, whether they are published or not. The documents may come from teaching and research institutions in France or abroad, or from public or private research centers.
L'archive ouverte pluridisciplinaire HAL, est destinée au dépôt et à la diffusion de documents scientifiques de niveau recherche, publiés ou non, émanant des établissements d'enseignement et de recherche français ou étrangers, des laboratoires publics ou privés. 


\title{
Oxadiazolone derivatives, new promising multi-target inhibitors against $M$. tuberculosis
}

\author{
Phuong Chi Nguyen ${ }^{\mathrm{a}, 1}$, Vincent Delorme ${ }^{\mathrm{b}, 1,2}$, Anaïs Bénarouche ${ }^{\mathrm{a}}$, Alexandre Guy ${ }^{\mathrm{c}}$, \\ Valérie Landry ${ }^{\mathrm{b}}$, Stéphane Audebert ${ }^{\mathrm{d}}$, Matthieu Pophillat ${ }^{\mathrm{d}}$, Luc Camoin ${ }^{\mathrm{d}}$, Céline Crauste ${ }^{\mathrm{c}}$, \\ Jean-Marie Galano ${ }^{\mathrm{c}}$, Thierry Durand ${ }^{\mathrm{c}}$, Priscille Brodin ${ }^{\mathrm{b}}$, Stéphane Canaan ${ }^{\mathrm{a}, *}$, \\ Jean-François Cavalier ${ }^{a}$,* \\ a Aix-Marseille Univ, CNRS, LISM, Institut de Microbiologie de la Méditerranée, Marseille, France \\ ${ }^{\mathrm{b}}$ Univ. Lille, CNRS, INSERM, CHU Lille, Institut Pasteur de Lille, U1019 - UMR 8204 - CIIL - Center for Infection and Immunity of Lille, Lille, France \\ ${ }^{\mathrm{c}}$ Institut des Biomolécules Max Mousseron (IBMM), UMR 5247, Université de Montpellier, CNRS, ENSCM, 15 Avenue Charles Flahault, 34093 Montpellier Cedex 5, \\ France \\ d Aix-Marseille Univ, Inserm, CNRS, Institut Paoli-Calmettes, CRCM, Marseille Protéomique, Marseille, France
}

\section{A R T I C L E I N F O}

\section{Keywords:}

Tuberculosis

Oxadiazolone

Lipolytic enzyme inhibitors

Activity-based probe (ABP)

\begin{abstract}
A B S T R A C T
A set of 19 oxadiazolone (OX) derivatives have been investigated for their antimycobacterial activity against two pathogenic slow-growing mycobacteria, Mycobacterium marinum and Mycobacterium bovis BCG, and the avirulent Mycobacterium tuberculosis (M. tb) $\mathrm{mc}^{2} 6230$. The encouraging minimal inhibitory concentrations (MIC) values obtained prompted us to test them against virulent $M$. $t b \mathrm{H} 37 \mathrm{Rv}$ growth either in broth medium or inside macrophages. The $\mathbf{O X}$ compounds displayed a diversity of action and were found to act either on extracellular $M$. $t b$ growth only with moderated $\mathrm{MIC}_{50}$, or both intracellularly on infected macrophages as well as extracellularly on bacterial growth. Of interest, all OX derivatives exhibited very low toxicity towards host macrophages. Among the six potential OXs identified, HPOX, a selective inhibitor of extracellular $M$. $t b$ growth, was selected and further used in a competitive labelling/enrichment assay against the activity-based probe Desthiobiotin-FP, in order to identify its putative target(s). This approach, combined with mass spectrometry, identified 18 potential candidates, all being serine or cysteine enzymes involved in $M$. $t b$ lipid metabolism and/or in cell wall biosynthesis. Among them, Ag85A, CaeA, TesA, KasA and MetA have been reported as essential for in vitro growth of $M . t b$ and/or its survival and persistence inside macrophages. Overall, our findings support the assumption that $\mathbf{O X}$ derivatives may represent a novel class of multi-target inhibitors leading to the arrest of $M$. $t b$ growth through a cumulative inhibition of a large number of Ser- and Cys-containing enzymes involved in various important physiological processes.
\end{abstract}

\section{Introduction}

With 10.4 million new cases and 1.7 million deaths in 2016, tuberculosis (TB) caused by the pathogenic species Mycobacterium tuberculosis (M. $t$ b) remains the leading cause of death worldwide from a single infectious agent [1]. Despite the quadritherapy treatment involving isoniazid (INH), pyrazinamide, rifampicin (RIF) and ethambutol, the introduction of new molecules on the market to strengthen or replace this first-line antibiotics regimen is a slow and tedious process $[2,3]$. Only a few drugs were able to pass the selection stages (e.g., bedaquiline [4], delamanid [5] and PA-824 [6]). However, the appearance and spread of multidrug-resistant (MDR), extensively drug-

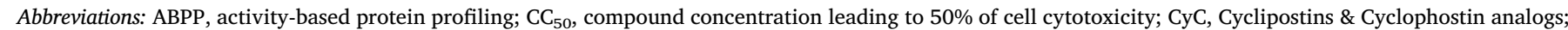

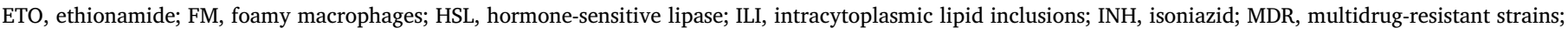

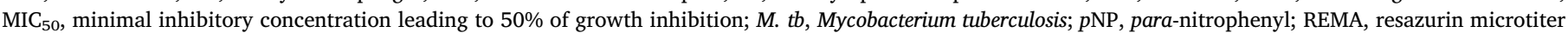

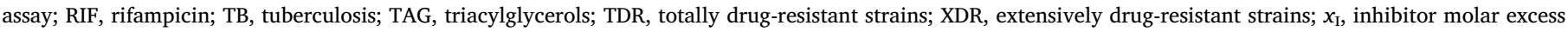
related to $1 \mathrm{~mol}$ of enzyme; $x_{\mathrm{I} 50}$, inhibitor molar excess leading to $50 \%$ enzyme inhibition

* Corresponding authors.

E-mail addresses: canaan@imm.cnrs.fr (S. Canaan), jfcavalier@imm.cnrs.fr (J.-F. Cavalier).

${ }^{1}$ Authors have contributed equally to this work.

${ }^{2}$ Current Address: Tuberculosis Research Laboratory, Institut Pasteur Korea, Seongnam-si, Gyeonggi-do 13488, Republic of Korea. 
A<smiles>O=c1[nH]nc(-c2ccncc2)o1</smiles>

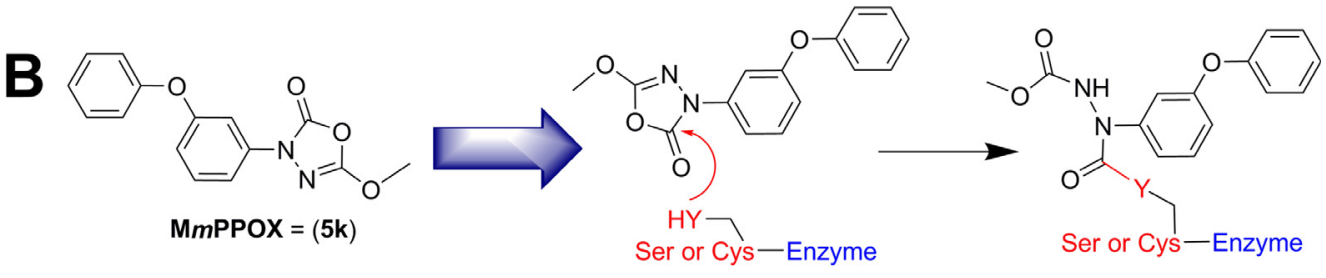

$\mathrm{YH}=\mathrm{OH}$ (Ser) or SH (Cys)

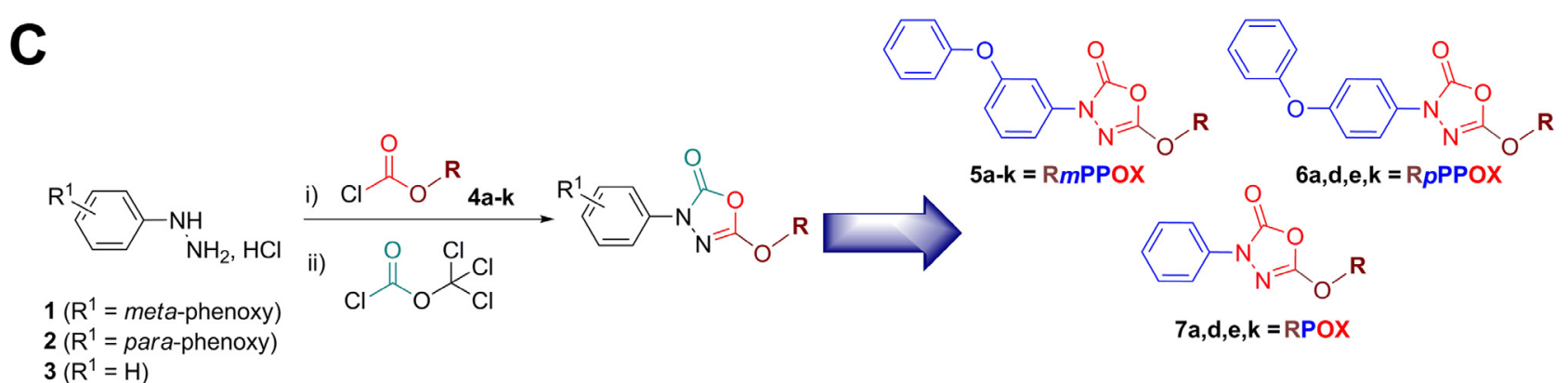

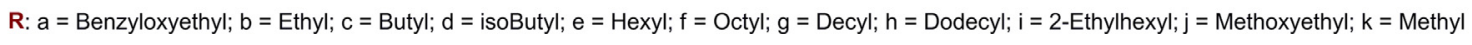

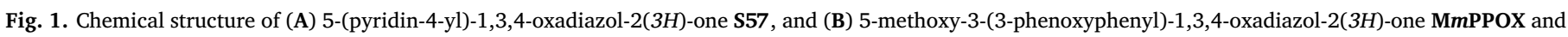

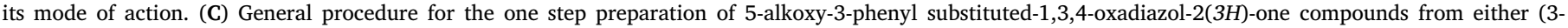

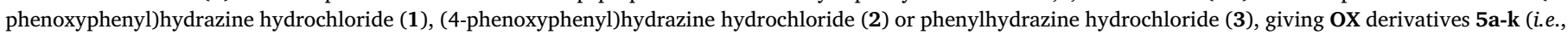

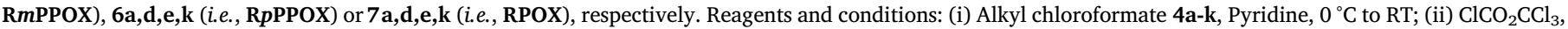
$\mathrm{CHCl}_{2}$, Pyridine, $0{ }^{\circ} \mathrm{C}$ to RT, 40-85\%. Adapted from [27].

resistant (XDR) and totally drug-resistant (TDR) strains [7-10] highlights the urgent need for finding new therapeutic options to fight against $M$. $t b$.

In this context, oxadiazolone-core (OX) compounds represent attractive tools. Compound S57 (Fig. 1A), initially described in 1954 $[11,12]$ as being active against TB [13-15], was used as template for the synthesis of 3,5-substituted 1,3,4-oxadiazole-2-one derivatives $[16,17]$. These molecules were found to exhibit interesting anti-mycobacterial activity against $M$. $t b \mathrm{H} 37 \mathrm{Rv}$, with minimal inhibitory concentrations (MIC) of $1.25-8 \mu \mathrm{g} / \mathrm{mL}$, comparable to those of INH $(0.5 \mu \mathrm{g} / \mathrm{mL})$ and RIF $(1.0 \mu \mathrm{g} / \mathrm{mL})$ [16,17]. Molecular modeling indicated that these compounds possessed all necessary features to block the enzymatic activity of the mycobacterial cytochrome P450-dependent $14 \alpha$-sterol demethylase ( $\mathrm{P}^{4} 50_{14 \mathrm{DMs}}$ ) [18], also a target for antifungal drug design [19]. These findings thus suggest the potential use of such OX derivatives as alternative therapeutic agents for TB [20].

Few years ago, we reported that the OX compound MmPPOX (Fig. 1B), a reversible inhibitor of the hormone-sensitive lipase (HSL) family of proteins [21,22], was able to inhibit the growth of $\boldsymbol{M}$. $t b$ with MIC values of around $15-25 \mu \mathrm{g} / \mathrm{mL}$ as determined on solid medium [23]. Keeping in mind its strong affinity towards the HSL family member proteins (Lip-HSL), we further investigated the in vitro inhibition of recombinant $M$. $t b$ Lip-HSL. As expected, the nine purified Lip-HSL enzymes tested were all strongly inhibited by MmPPOX, which reacted with the catalytic serine residue by forming a covalent but (slowly) reversible bond (i.e., carbamate or thiocarbamate bond, Fig. 1B). Such an inhibitor could then be considered as a long-life substrate rather than a true inhibitor as already observed with Orlistat (also named Tetrahydrolipstatine or THL), a representative member of reversible serine hydrolase inhibitors [24-26].

From these first results, a new series of 18 lipophilic OX derivatives based on MmPPOX core-structure have been synthesized (Fig. 1C) and tested for their anti-mycobacterial activities. More precisely, each oxadiazolone molecule has been tested against $M$. tb H37Rv for (i) its capacity to inhibit in vitro growth; (ii) its antitubercular activity on $M$. tb-infected macrophages, and (iii) its cytotoxicity towards macrophages. Interestingly, some analogs were found to inhibit $M$. $t b$ growth in vitro and/or inside macrophages without any significant toxicity to host cells. In addition, using an activity-based protein profiling (ABPP) assay, the potential target enzymes of HPOX, acting only on $M$. $t b$ extracellular growth, were further identified.

\section{Results and discussion}

\subsection{Synthesis of oxadiazolone-core $(\mathrm{OX})$ derivatives}

The set of new 18 lipophilic OX derivatives based on MmPPOX core-structure was designed by varying the nature of the $\mathrm{R}$ chain and/or the positioning of the phenoxy group (in meta or para position) when present (Fig. 1C), and synthesized as previously reported [27]. The (phenoxy)phenyl group, proposed to be responsible for strong hydrophobic interactions and structural stiffening [27], was conserved in most of the new candidate inhibitors. In addition, modifying the $\mathbf{R}$ chain born by the oxadiazolone ring allow an investigation of the influence of the lipophilicity on the antibacterial activity exerted by these molecules. To remain consistent with previous studies involving such compounds $[23,27]$, we have decided to use the specific nomenclature already developed for these derivatives noted $\mathbf{R m}$ (or $\boldsymbol{p}$ )PPOX; where $\mathbf{m}$ (or $\boldsymbol{p}$ )P represents the meta (or para)-Phenoxy group when present; $\mathbf{P}$ the phenyl group; $\mathbf{O X}$ the Oxadiazolone core; and $\mathbf{R}$ the alkyl chain (i.e., Be, benzyloxyethyl; M; methyl, E, ethyl; B, butyl; iB, isobutyl; $\mathrm{H}$, hexyl; O, octyl; Eh, 2-ethylhexyl; D, decyl; Do, dodecyl; Me, methoxyethyl).

\subsection{Susceptibility testing on selected mycobacteria}

The antibacterial properties of the $\mathbf{O X}$ compounds were first evaluated towards three slow-growing mycobacteria: M. marinum, $M$. bovis BCG and $M$. $t b \mathrm{mc}^{2} 6230$, a H37Rv strain with its RD1 region and panCD genes deleted, resulting in an avirulent pan $(-)$ phenotype [28]. The corresponding $\mathrm{MIC}_{50}$ values, as determined by the REMA assay [29-32], are reported in Table 1. First, it is noteworthy that the concentrations needed to inhibit $50 \%$ of the bacterial growth $\left(\mathrm{MIC}_{50}\right.$ ) 
Table 1

Antibacterial activities of the oxadiazolone derivatives against $M$. marinum, $M$. Bovis BCG and $M$. $t b \mathrm{mc}^{2} 6230$ using the REMA method.

\begin{tabular}{|c|c|c|c|}
\hline \multirow[t]{2}{*}{ Compounds } & \multicolumn{3}{|c|}{$\mathrm{MIC}_{50}(\mu \mathrm{M})$} \\
\hline & M. marinum & M. bovis BCG & M. $t b \mathrm{mc}^{2} 6230$ \\
\hline INH & 20.5 & 0.71 & 1.5 \\
\hline RIF & 1.4 & 0.027 & 0.015 \\
\hline MmPPOX & 7.0 & 15.0 & 71.3 \\
\hline МpРPOX & 11.5 & 39.9 & $>120$ \\
\hline MPOX & 52.9 & $>120$ & 89.8 \\
\hline EmPPOX & 3.4 & 7.1 & $>120$ \\
\hline MemPPOX & 2.7 & 9.4 & 91.2 \\
\hline BmPPOX & 4.1 & 6.6 & 52.2 \\
\hline iBmPPOX & 13.6 & 4.4 & 57.2 \\
\hline іВpРPOX & 6.9 & 8.5 & 31.1 \\
\hline iBPOX & 2.5 & 5.7 & $>120$ \\
\hline HmPPOX & 11.1 & 5.8 & 48.8 \\
\hline НрРРОХ & 3.4 & 14.0 & 41.3 \\
\hline HPOX & 2.6 & 3.5 & 40.5 \\
\hline BemPPOX & 5.6 & 10.5 & 49.5 \\
\hline ВерРРОХ & 10.1 & 18.5 & 44.5 \\
\hline BePOX & 1.9 & 6.6 & 33.2 \\
\hline OmPPOX & 8.0 & 11.0 & 44.7 \\
\hline EhmPPOX & 8.3 & 8.1 & 43.3 \\
\hline DmPPOX & 10.5 & 80.8 & $>120$ \\
\hline DomPPOX & 19.5 & 22.6 & $>120$ \\
\hline
\end{tabular}

${ }^{\text {a }}$ Experiments were performed as described in Section 4. $\mathrm{MIC}_{50}$ : compound minimal concentration leading to $50 \%$ of growth inhibition, as determined by the

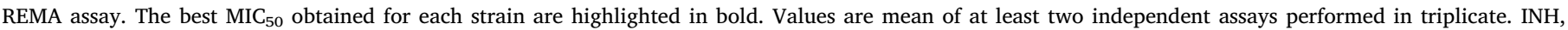
isoniazid; RIF, rifampicin.

obtained for rifampicin (RIF) and isoniazid (INH), used here as reference antibiotics, were in agreement with literature data [33-35].

Nearly all 19 OXs were active against $M$. bovis BCG and M. marinum growth (Table 1). However, with $\mathrm{MIC}_{50}$ values in the range $1.9-53 \mu \mathrm{M}$, M. marinum was nearly 2-times more sensitive to $\mathbf{O X}$ compounds than M. bovis BCG (MIC $_{50}$ from 3.5 to $>120 \mu \mathrm{M}$ ). BePOX, HPOX and iBPOX, for which the phenoxy substituent is absent, exhibited the most potent antibacterial activity towards $M$. marinum, with mean $\mathrm{MIC}_{50}$ of $2.3 \pm 0.33 \mu \mathrm{M}$, comparable to that of RIF $(1.4 \mu \mathrm{M})$. Interestingly, these three OX compounds were also among the best inhibitors of $M$. bovis BCG growth; HPOX being the best one ( $\left.\mathrm{MIC}_{50}=3.5 \mu \mathrm{M}\right)$.

From these encouraging data obtained using two slow-growing mycobacteria, it was tempting to extrapolate that these OXs would behave in a similar way against $M$. $t b$ growth and conclude that the same three compounds, i.e. BePOX, HPOX and iBPOX, would then be promising anti-TB molecules.

Drug susceptibility testing of the 19 OXs was thus further assessed using the non-virulent $M$. $t b \mathrm{mc}^{2} 6230$ strain. Among all tested compounds, 14 OXs were active against $M$. $t b \mathrm{mc}^{2} 6230$. The two best growth inhibitors obtained were iBpPPOX and BePOX, which displayed similar $\mathrm{MIC}_{50}$ value (mean $32.1 \pm 1.0 \mu \mathrm{M}$ ). In all other cases, MIC $_{50}$ values were indicative either of a weak (mean $\mathrm{MIC}_{50}=84.1 \pm 9.1 \mu \mathrm{M}$ for MmPPOX, MPOX and MemPPOX), or a moderate (mean $\mathrm{MIC}_{50}=46.9 \pm 5.1 \mu \mathrm{M}$ for BmPPOX, iBmPPOX, HmPPOX, HpPPOX, HPOX, OmPPOX, EhmPPOX, BemPPOX and BepPPOX) antibacterial activity (Table 1). From these data, $M . t b$ $\mathrm{mc}^{2} 6230$ was found nearly 13 - and 5-times less sensitive to the $\mathbf{O X}$ compounds than $M$. marinum and $M$. bovis BCG, respectively.

Surprisingly, iBPOX, which differs from BePOX and HPOX by the length of its $\mathbf{R}$ substituent, was not active against this mycobacteria. Moreover, no clear trends or rules in terms of structure-activity relationships (SAR) have emerged regarding the potency of these oxadiazolone-core compounds against $M$. marinum and $M$. bovis BCG. Indeed, increasing the lipophilicity by varying the nature of the $\mathbf{R}$ chain on the oxadiazolone ring and/or the positioning of the phenoxy group when present had no real impact on the anti-mycobacterial activity.

Interestingly, with $M . t b \mathrm{mc}^{2} 6230$, some SAR tendencies can however be set up. First, and as mentioned above, the positioning of the phenoxy group in meta or para position has no real impact on the antibacterial activity of the corresponding compounds (i.e., MmPPOX $v s$. MpPPOX; iBmPPOX vs. iBpPPOX; HmPPOX vs. HpPPOX; BemPPOX vs. BepPPOX). Remarkably, iBPOX bearing the short chain isobutyl has no activity as compared to the phenoxyphenyl derivatives iBpPPOX and $\mathbf{i B m P P O X}$. This is however not the case with the medium chains hexyl and benzyloxyethyl OXs, for which the respective activity of HPOX and BePOX is retained and even slightly better than HmPPOX \& HpPPOX on the one hand, and BemPPOX \& BepPPOX on the other hand. Finally, in absence of the bulky phenoxy group, the best $\mathrm{MIC}_{50} \mathrm{~S}$ against M. $t b \mathrm{mc}^{2} 6230$ were also obtained with HPOX and BePOX $v s$. MPOX and iBPOX. In brief, the $\mathbf{R}$ chain length thus seems to affect the potency of the tested compounds. More globally, the best growth inhibitors were found to carry a middle chain length of around 6-9 carbon atoms (i.e., hexyl, 2-ethylhexyl, octyl or benzyloxyethyl chains). Longer or shorter chain's OXs (i.e., methyl, methoxyethyl, ethyl, decyl or dodecyl) exhibited no or only very poor activity.

In summary, iBpPPOX displayed the best, while still moderate, antibacterial activity against $M$. $t b \mathrm{mc}^{2} 6230$. The reason why such differences exist between the activity of the OX compounds against $M$. marinum and $M$. bovis BCG, compared to $M$. tb, is not clear and will need further studies to be elucidated; but differences in membrane composition and permeability are likely playing a role in this phenotype.

\subsection{High-content screening assay on virulent M. tb H37Rv}

As recently observed for another class of potent $M$. $t b$ growth inhibitors, the Cyclipostins \& Cyclophostin analogs (CyC) [31], MIC 50 values determined against $M$. $t b \mathrm{mc}^{2} 6230$ do not necessarily correlate with the activity against $M$. $t b \mathrm{H} 37 \mathrm{Rv}$, particularly the activity against 
Table 2

Antitubercular activities of the most active $\mathbf{O X}$ derivatives against $M$. tb H37Rv. ${ }^{\text {a }}$

\begin{tabular}{|c|c|c|c|}
\hline \multirow[t]{2}{*}{ Compounds } & \multirow{2}{*}{$\begin{array}{l}\text { Extracellular } \\
\text { growth } \\
\mathrm{MIC}_{50}(\mu \mathrm{M})\end{array}$} & \multicolumn{2}{|c|}{$\begin{array}{l}\text { Intracellular } \\
\text { macrophage } \\
\text { growth }^{\text {b }}\end{array}$} \\
\hline & & $\begin{array}{l}\mathrm{MIC}_{50} \\
(\mu \mathrm{M})\end{array}$ & $\begin{array}{l}\mathrm{CC}_{50} \\
(\mu \mathrm{M})\end{array}$ \\
\hline $\mathrm{INH}^{\mathrm{c}}$ & 1.2 & 1.2 & $>150$ \\
\hline $\mathrm{RIF}^{\mathrm{c}}$ & 0.01 & 2.9 & 24 \\
\hline $\mathrm{ETO}^{\mathrm{c}}$ & 6.0 & 6.0 & 120 \\
\hline іВpРPOX & 32.0 & 8.5 & $>100$ \\
\hline iBPOX & $>50$ & 17.1 & $>100$ \\
\hline НрРРОХ & $>50$ & 9.5 & $>100$ \\
\hline HPOX & 44.6 & $\begin{array}{l}\text { No } \\
\text { effect }\end{array}$ & $>100$ \\
\hline ВерРPOX & $>50$ & 3.5 & $>100$ \\
\hline BePOX & 30.8 & $\begin{array}{l}\text { No } \\
\text { effect }\end{array}$ & $>100$ \\
\hline
\end{tabular}

\footnotetext{
${ }^{\text {a }}$ Experiments were performed as described in Section 4. $\mathrm{MIC}_{50}$ : compound minimal concentration leading to $50 \%$ of growth inhibition. $\mathrm{CC}_{50}$ : compound concentration leading to $50 \%$ of cell cytotoxicity. Each value is the mean \pm SD for a triplicated dose-response. Experiments were conducted at least twice with consistent results.

b Raw264.7 macrophages were infected by $M$. $t b$ H37Rv-GFP at a MOI of 2:1.

c Data from [36]. INH, isoniazid; RIF, rifampicin; ETO, ethionamide.
}

intracellular bacteria.

Consequently, each of the 19 OX derivatives have been further evaluated for their specific antitubercular activity against extracellularly- and intracellularly-growing virulent $M$. $t b$ H37Rv-GFP strain, using a high-content screening assay based on the fluorescence measurement of GFP-expressing bacteria. In vitro growth (i.e., extracellular assay) of $M$. $t b$ H37Rv-GFP was first monitored after 5 days at $37^{\circ} \mathrm{C}$ in presence of increasing concentrations of candidate inhibitors [31,36-38]. Intracellular growth of $M$. tb H37Rv-GFP was also assessed following a 5-day exposure of infected Raw264.7 murine macrophage cell line to the various $\mathbf{O X}$ compounds. In this case, the percentage of infected cells, the total number of bacteria, the number of bacteria per infected cells, as well as the number of living host cells allowed us to determine the $\mathrm{MIC}_{50}$ of the compound $[36,39,40]$. In subsequent experiment, the concentration leading to $50 \%$ of host cell cytotoxicity, i.e. $\mathrm{CC}_{50}$, were also determined in absence of infection.

Among all tested molecules, 6 potential ox candidates exhibited interesting antitubercular properties (Table 2 and Fig. 2). BePOX and HPOX impaired exclusively $M$. $t b$ growth in culture broth medium with the same moderate $\mathrm{MIC}_{50}$ (30.8 and $44.6 \mu \mathrm{M}$, respectively) than obtained previously on $M$. $t b \mathrm{mc}^{2} 6230$. In contrast, iBPOX, HpPPOX and BepPPOX showed a clear preference against intracellularly-replicating mycobacteria with similar $\mathrm{MIC}_{50}$ values $(3.5-17.1 \mu \mathrm{M})$ than the first line antibiotics. Of interest, only iBpPPOX exhibited moderate $(32.0 \mu \mathrm{M})$ to quite good $(8.5 \mu \mathrm{M})$ activity against both extracellular and intramacrophagic $M$. $t b$, respectively (Fig. 2).

Beside antibacterial activity, significantly, all these 6 OX inhibitors exhibited very low toxicity towards host macrophages with

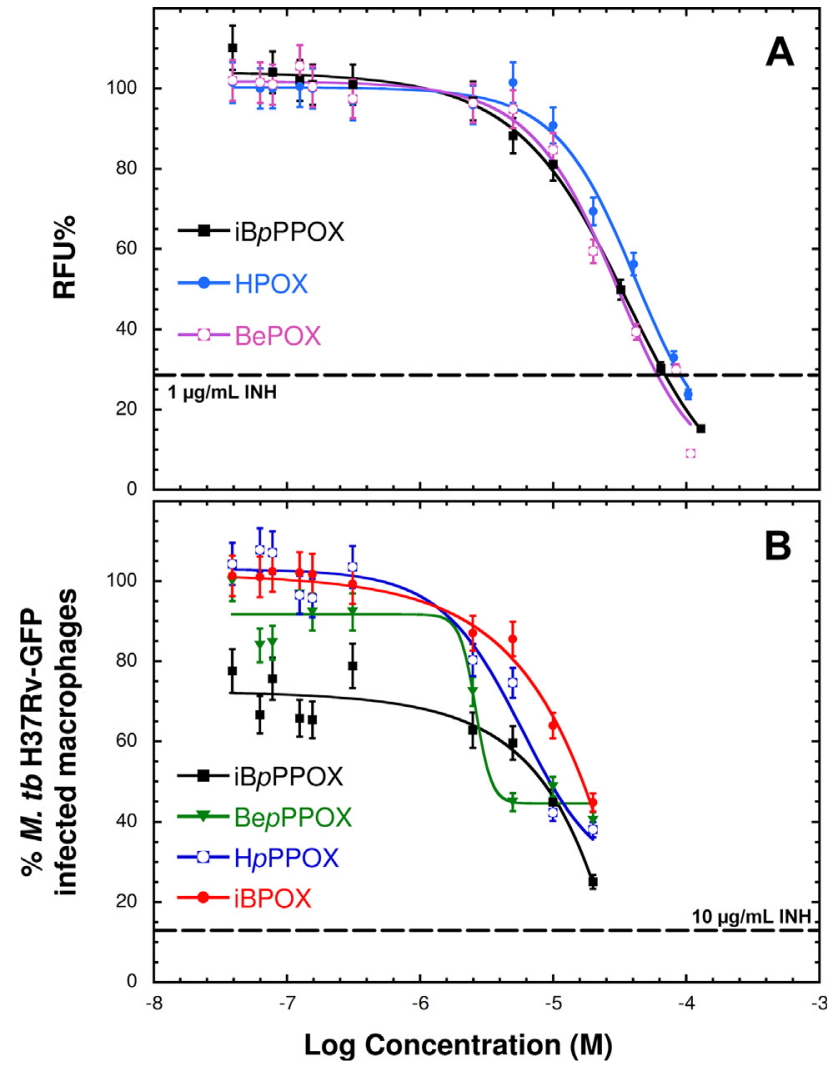

Fig. 2. In vitro and ex vivo dose-response activity of the $\mathrm{OX}$ derivatives against M. tb H37Rv. (A) Activity of BePOX, iBpPPOX and HPOX against GFP-expressing $M$. $t b$ replicating in broth medium, expressed as normalized relative fluorescence units (RFU\%). The dashed line represents the level of inhibition $(\sim 70 \%)$ reached with $1 \mu \mathrm{g} / \mathrm{mL}(=7.3 \mu \mathrm{M}) \mathrm{INH}$ as control. The $\mathrm{MIC}_{50}$ of BePOX, iBpPPOX and HPOX replicating in culture broth medium were $30.8 \mu \mathrm{M}, 32.0 \mu \mathrm{M}$ and $44.6 \mu \mathrm{M}$, respectively. (B) Activity of iBpPPOX, BepPPOX, HpPPOX and iBPOX against $M$. tb replicating inside Raw264.7 macrophages. Results are expressed as the percentage of infected macrophages after 5 days post-infection. The dashed line represents the level of inhibition $(\sim 87 \%)$ reached with $10 \mu \mathrm{g} / \mathrm{mL}(=73 \mu \mathrm{M})$ INH as control. The $\mathrm{MIC}_{50}$ of BepPPOX, iBpPPOX, HpPPOX and iBPOX replicating inside macrophages were $3.5 \mu \mathrm{M}, 8.5 \mu \mathrm{M}, 9.5 \mu \mathrm{M}$ and $17.1 \mu \mathrm{M}$, respectively. Each value is the mean \pm SD for a triplicated dose-response. Experiments were conducted at least twice with consistent results.

$\mathrm{CC}_{50}>100 \mu \mathrm{M}$, similarly to INH $\left(\mathrm{CC}_{50}>150 \mu \mathrm{M}\right)$ and ethionamide $\left(\mathrm{CC}_{50} \geq 120 \mu \mathrm{M}\right)$, two potent anti-TB drugs (Table 2). Their respective selectivity index ( $\left.\mathrm{SI}=\mathrm{CC}_{50} / \mathrm{MIC}_{50}\right)$ on intramacrophagic $M$. tb vs. Raw264.7 cells was thus found to be in a range from 5.8 and up to 28 . While these are preliminary results that would need to be confirmed in other cell types including hepatocytes, they are encouraging for further improvement of the OX compounds. This absence of cytotoxicity was actually not obvious, given the number of (Ser/Cys)-enzymes present in host cells and the predicted potency of the OX compounds to target these classes of enzymes.

Interestingly, the observed differences in the behavior of $\mathbf{O X}$ compounds; in particular the higher activity against intracellular bacteria than against extracellular ones, have also been reported in the case of the CyC compounds family [31]. As previously discussed above, inhibition of $M$. $t b \mathrm{H} 37 \mathrm{Rv}$ may result from several (and probably different) mechanisms of action or penetration of the $\mathbf{O X}$ derivatives. With the hexyl and benzyloxyethyl chain, the absence/presence of the phenoxy group in para position clearly shifted the activity of the corresponding OX from extracellular- (i.e., HPOX \& BePOX) to intracellularreplicating bacilli (i.e., HpPPOX \& BepPPOX). On the other hand, with the short isobutyl chain, both iBpPPOX and iBPOX are found most 
active against intramacrophagic-replicating $M . t b$.

From these findings, it is tempting to assume that these OX compounds thus lead to the inhibition of specific but most likely distinct mycobacterial target enzymes between intramacrophagic- vs. extracellularly-replicating bacilli.

\subsection{Targets identification by Activity-based protein profiling}

Based on the aforementioned results, and taking into account their strong affinity for Serine and/or Cysteine (Ser/Cys)-based enzymes (Fig. 1B), one can hypothesize that $\mathbf{O X}$ inhibitors might target and impair the activity of various enzymes involved in several processes of $M$. $t b$ pathogenic life cycle, thus resulting in bacterial death without any cytotoxicity towards host cells. Accordingly, target(s) identification experiments were conducted by applying an activity-based protein profiling (ABPP) approach [41-44]. In order to take into account the penetration/diffusion of the inhibitor through the mycobacterial cell wall, all experiments have been performed on living bacterial cells and not with a lysate, as previously described [31].

Here, HPOX, that selectively inhibits $M$. tb growth only in culture broth medium, was selected for such experiments. $M$. $t b \mathrm{mc}^{2} 6230$ cells were grown to log phase and then incubated with HPOX compound or DMSO as a control. After cell lysis, part of the lysate was used for competitive probe labelling/enrichment assay using the DesthiobiotinFP probe, targeting (Ser/Cys)-based enzymes [43] (Fig. 3). In parallel, the remaining lysate was incubated with TAMRA-FP, also targeting (Ser/Cys)-based enzymes [43], to reveal the candidates presumably reacting with HPOX on SDS-PAGE gel, using fluorescence scanning [31]. Around 9 distinct bands labelled by TAMRA-FP were visible in the fluorescence readout (Fig. 3B -lane E) and could also be detected by silver staining after release of the enzymes captured by DesthiobiotinFP (Fig. 3B - lane B). In contrast, pre-treatment with HPOX (Fig. 3A) resulted in a decrease in fluorescence intensity of all visible bands, as exemplified by the black arrows in Fig. 3B - lane D. Indeed, the enzymes previously inactivated by HPOX inhibitor will thus be unable to further react with the probes. The respective enriched mixtures (Fig. 3B - lanes A-B) were digested with trypsin and the resulting peptides were analyzed by liquid chromatography-tandem mass spectrometry (LCMS/MS) followed by subsequent label free quantification analysis. The proteins that were also found in the control experiment (i.e., Fig. 3B lane A: DMSO alone for unspecific binding to streptavidin-magnetic beads) were not taken into account.

The resulting mycobacterial targets of HPOX were displayed as volcano plot (Fig. 4). Only proteins identified with a permutation false discovery rate (pFDR) of $5 \%$ and a score threshold value $\geq 60$ were selected, therefore leading to a panel of 18 distinct proteins (Table 3). These identified enzyme candidates ranged in their functional category from intermediary metabolism/respiration (6 proteins), lipid metabolism (5 proteins), cell wall/cell processes ( 6 proteins), and virulence/ detoxification/adaptation (1 protein) (Table 3 ).

As expected, the identified proteins targeted by HPOX were all (Ser/ Cys)-based enzymes. Among them, a variety of Ser/Cys hydrolases were detected. These included the putative $\beta$-lactamase Rv1367c possibly involved in cell wall biosynthesis; two amidases AmiC (Rv2888c) and AmiD (Rv3375); BpoC (Rv0554) a putative serine hydrolase [43]; two members of the lipase family Lip (LipH [45] and LipV [46]); three Cutinase-like proteins (Cfp21, Cut2 and Cut3) [47]; and the monoacylglycerol lipase Rv0183 [48].

More interestingly, 5 out of 18 identified proteins have been annotated as essential enzymes [49] (Table 3). These include the antigen 85 complex, Ag85A (Rv3804c), Ag85B (Rv1886c) and Ag85C (Rv0129c) [50]; the thioesterase TesA (Rv2928) [51]; the carboxylesterase CaeA (Rv2224c) [52]; the beta-ketoacyl synthase KasA (Rv2245) [53]; and the sole putative $\alpha / \beta$-hydrolase MetA (Rv3341) belonging to the homoserine $O$-acetyltransferase family proteins in $M$. $t b$ [54].

\subsection{TesA, Rv0183 and Cfp21 are inhibited by HPOX}

In order to validate some targets of HPOX inhibitor, we further investigated its ability to efficiently inhibit the activity of three identified proteins; i.e., TesA, Cfp21 and Rv0183. Coding sequences were amplified from $M$. $t b$ genome, cloned in $E$. coli and the enzymes produced in recombinant form and purified as previously reported $[48,55]$. Purified proteins were then individually incubated for $30 \mathrm{~min}$ at room temperature with HPOX at various inhibitor molar excess $\left(x_{\mathrm{I}}\right)$. The residual enzyme activity was then measured using para-nitrophenyl caprylate (pNPC-8) as substrate for TesA and Cfp21 [55], and monoolein as substrate in the case of Rv0183 [48]. The variation in the residual enzyme activity allowed determination of the inhibitor molar excess leading to $50 \%$ enzyme inhibition, i.e., $x_{\mathrm{I} 50}$ value $[27,56]$. Thereby, a $x_{\text {I50 }}$ value of 0.5 is synonymous with a $1: 1$ stoichiometric ratio between the inhibitor and the lipolytic enzyme, and is therefore the highest level of inhibitory activity that can be achieved.

As depicted in Fig. 5, a clear dose-dependent inhibition was observed with the three enzymes. TesA, Rv0183 and Cfp21 were indeed strongly inactivated, with $97.6 \%$ and $88.5 \%$ inhibition at $x_{I}=20$, respectively (Fig. 5, inset). Interestingly, HPOX was found to react almost stoichiometrically with pure TesA and Rv0183 as confirmed by their respective $x_{\mathrm{I} 50}$ values of around 0.60 . These results clearly demonstrate that these three lipolytic enzymes are effective targets of HPOX.

The fact that these OXs derivatives behave against $M$. $t b$ extracellular growth similarly to two other well-known non-specific (Ser/ Cys)-enzyme inhibitors, namely Orlistat (MIC $\sim 25 \mu \mathrm{M}$ ) [41,57] and the human lysosomal acid lipase inhibitor lalistat (MIC $\sim 25-50 \mu \mathrm{M}$ ) [42], support the assumption that HPOX, and certainly all the other active $\mathbf{O X}$ compounds, may act as multi-target inhibitors by impairing the activities of multiple non-essential lipolytic enzymes as well as essential proteins involved in various important physiological pathways of $M$. $t b$ life cycle.

Overall, it is now acknowledged that the lipolytic enzymes containing a catalytic Ser or Cys residue in their active site are not only involved in the host-pathogen cross-talk [58], but also play several roles in the physiopathology of the disease, in particular by recycling fatty acids from host lipids, a key element favoring $M$. $t b$ reactivation $[48,59]$ and survival in dormancy [60]. M. $t b$ indeed induces the formation of lipid bodies (LB) inside infected macrophages, giving the cells a foamy appearance. In foamy macrophages (FM), bacilli accumulate lipids within intracytoplasmic lipid inclusions (ILI) [61-64], which allow the bacteria to persist in a non-replicating state. In FM, several mycobacterial lipolytic enzymes of $M$. tb hydrolyze host triacylglycerols (TAG) from LB and the resulting fatty acids are stored within ILI as newly synthesized TAGs. Consequently, although they exhibited moderate MIC $_{50}$ values against $M$. $t b$ H37Rv as compared to classical antibiotics or the more recent $\mathrm{CyC}$ analogs [31]; OX compounds may however represent attractive chemical tools for identifying such (Ser/ Cys)-containing enzymes in living mycobacteria, studying the regulation of ILI formation in infected FM [65], and thus provide a better understanding of how bacilli can persist inside lipid-rich FM.

\section{Conclusion}

In conclusion, we have developed a new series of promising oxadiazolone-core compounds, active against three pathogenic mycobacteria. By blocking extracellular and/or intracellular $M$. $t b$ growth, we anticipate that these $\mathbf{O X}$ probes could thus provide interesting insights in the mechanisms operating during mycobacterial replication, persistence and/or reactivation, which are major issues for deciphering the susceptibility and the general development of TB. Moreover, as these compounds target bacterial pathway yet unexploited by anti-TB compounds, the identification of the mycobacterial enzymes inhibited by these OX compounds in vivo may contribute to background information for the development of new therapeutic strategies for 


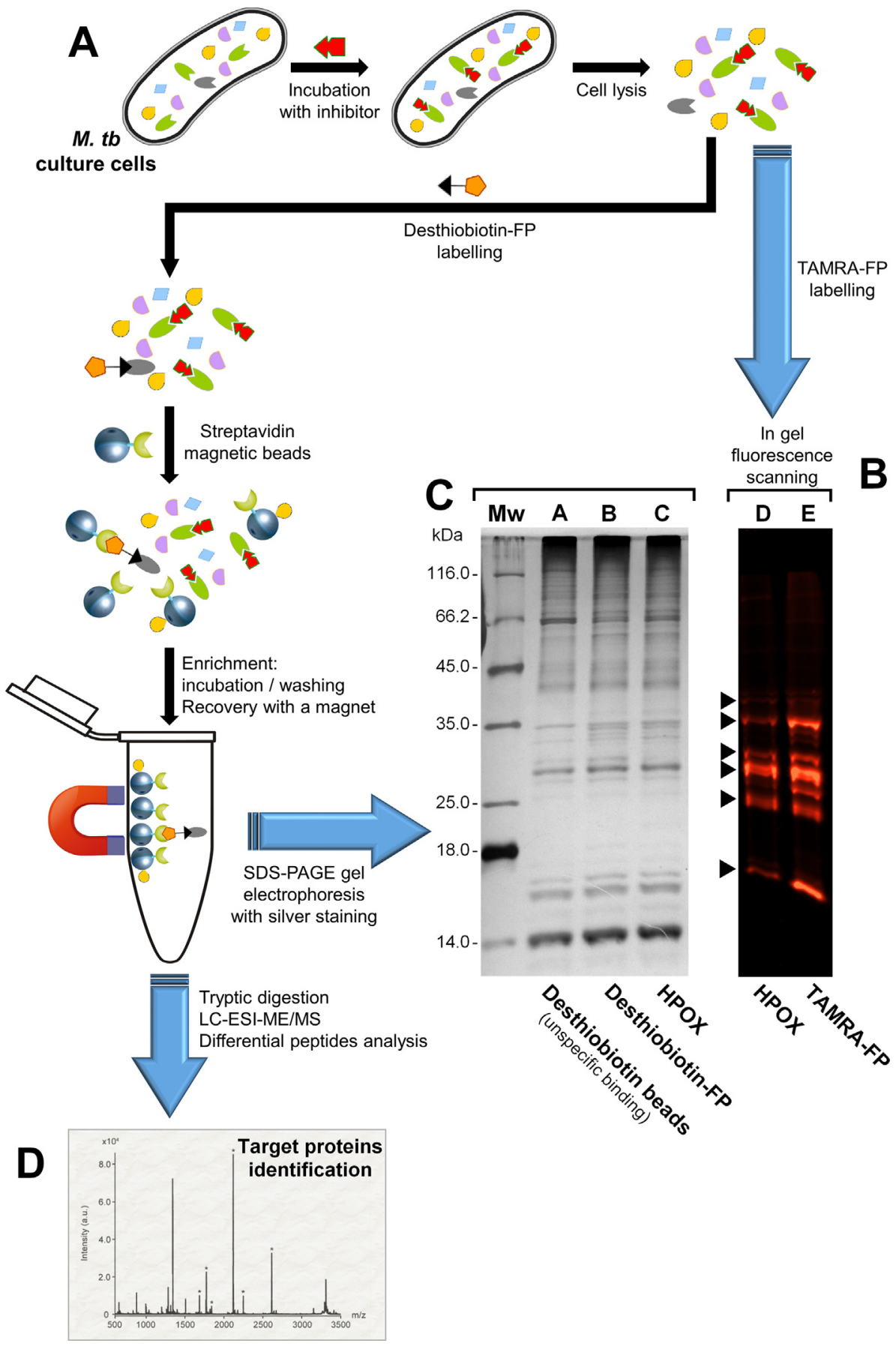

Fig. 3. Activity based protein profiling (ABPP) workflow for the identification of the proteins covalently bound to OX inhibitors. (A) Cell culture of $M$. $t b \mathrm{mc}^{2} 6230$ was pre-treated with selected HPOX inhibitor prior to cell lysis and further incubation with TAMRA-FP or Desthiobiotin-FP probe. In this latter case, samples were then treated with streptavidin-magnetic beads for the capture and enrichment of labelled proteins. (B-C) Equal amounts of proteins obtained in A were separated by SDS-PAGE and visualized by in-gel fluorescence (right panel lanes D-E: TAMRA detection) or silver staining (left panel - lanes A-C). Enzymes whose TAMRA-FP labelling is impeded because of the presence of HPOX in their active-site are shown by arrowheads. (D) Tryptic digestion followed by tandem mass spectrometry analyses and subsequent differential proteomics analysis allowed identifying the target proteins.

elimination of either actively replicating or latent bacilli from infected individuals. Accordingly, given the importance of such (Ser/Cys)-enzymes for $M$. $t b$ viability during infection, they should represent new attractive drug targets. Such experiments are currently underway, and will be reported in due course.

\section{Experimental Section}

\subsection{Chemistry}

The first 13 oxadiazolone derivatives $\mathbf{5 a}-\mathbf{k}, \mathbf{6 k}$ and $\mathbf{7 k}$ were synthesized as described previously $[27,66]$. The new six derivatives 6a,d,e and 7a,d,e were prepared from commercial (4-phenoxyphenyl) hydrazine hydrochloride (2) and phenylhydrazine hydrochloride (3), respectively, by performing both the coupling reaction with alkyl chloroformate 2a-k (step i) and the cyclization reaction with diphosgene (step ii) in a one-pot two-steps reaction [27]. All compound were at least $98 \%$ pure as determined by HPLC analysis [27]. Stock solutions $(4 \mathrm{mg} / \mathrm{mL})$ in which the oxadiazolone compounds were found to be completely soluble in dimethyl sulfoxide (DMSO), were prepared prior to drug susceptibility testing. See Supplementary Material for NMR, HPLC analysis and HRMS spectra of the new six OX derivatives.

4.1.1. General procedure for the one step preparation of 5-alkoxy-3-aryl1,3,4-oxadiazol-2(3H)-one compounds

4.1.1.1. 5-(2-(benzyloxy)ethoxy)-3-(3-phenoxyphenyl)-1,3,4-oxadiazol2(3H)-one ( $6 \boldsymbol{a}=\mathbf{B e p P P O X )}$. (4-phenoxyphenyl)hydrazine hydrochloride [66] 2 (8.2 g, $34.6 \mathrm{mmol}, 1$ equiv.) and 1-methyl pyrrolidone $(2.41 \mathrm{~mL}$, $31.1 \mathrm{mmol}, 0.9$ equiv.) were dissolved in dry pyridine $(700 \mathrm{~mL})$. The solution was cooled in an ice bath to $0^{\circ} \mathrm{C}$. Then, 2-benzyloxyethyl 


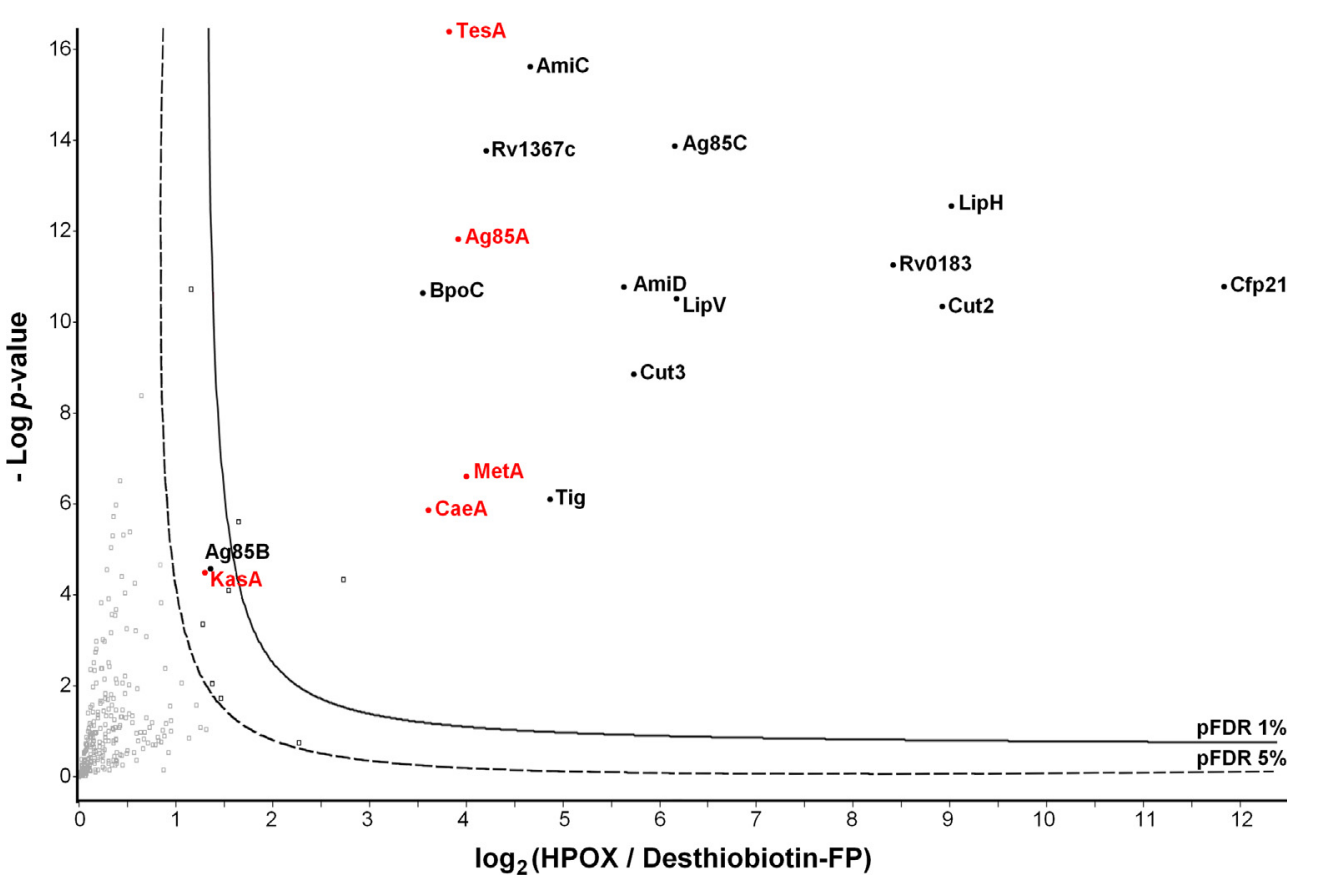

Fig. 4. Volcano plot of proteomic analysis of HPOX in M. $t b \mathrm{mc}^{2} 6230$ culture. Volcano plot showing the significance twosample $t$-test (-Log $\mathrm{p}$-value) versus foldchange (Log2 (LFQ normalized intensity in HPOX versus Desthiobiotin-FP condition) on the $y$ and $x$ axes, respectively. Here the plot is zoomed on the positive difference between the two conditions. The full line is indicative of protein hits obtained at a permutation false discovery rate of $1 \%$ (pFDR). Only protein hits obtained at a pFDR of 5\% (dashed line) and with a score threshold value $\geq 60$ were selected, and are highlighted in black (non-essential) or in red (essential). Data results from two different experiments processed three times. (For interpretation of the references to colour in this figure legend, the reader is referred to the web version of this article.) chloroformate $4 \mathrm{a}(6.87 \mathrm{~mL}, 38.6 \mathrm{mmol}, 1.1$ equiv.) was added dropwise over a period of $30 \mathrm{~min}$ at $0-5{ }^{\circ} \mathrm{C}$ and allowed to stir for $1 \mathrm{~h}$ at $0{ }^{\circ} \mathrm{C}$ and $1 \mathrm{~h}$ at room temperature. The reaction mixture was diluted by addition of methylene chloride $(300 \mathrm{~mL})$ and dry pyridine $(70 \mathrm{~mL})$ and the mixture was cooled at $-10{ }^{\circ} \mathrm{C}$ using an ice-salt bath. A solution of diphosgene $(6.26 \mathrm{~mL}, 51.8 \mathrm{mmol}, 1.5$ equiv.) in methylene chloride $(30 \mathrm{~mL})$ was added dropwise using a syringe pump over a period of $1 \mathrm{~h}$ while maintaining $-10^{\circ} \mathrm{C}$ with an ice-salt bath. After the addition is complete the reaction mixture stirred $1 \mathrm{~h}$ at $-10^{\circ} \mathrm{C}$ and $2 \mathrm{~h}$ at room temperature. The reaction mixture was diluted with water $(1 \mathrm{~L})$ and extracted with diethyl ether $(3 \times 250 \mathrm{~mL})$. The combined organic layers were washed with water $(2 \times 250 \mathrm{~mL})$ and brine $(3 \times 100 \mathrm{~mL})$, dried over $\mathrm{MgSO}_{4}$, and filtered. Purification by column chromatography using cyclohexane/ethyl acetate $(98 / 2$ to $95 / 5, v / v)$ as eluent gave the title compound 6a (BepPPOX) as a yellow oil (9.94 g, 71\%). Analytical data for BepPPOX: $R_{f}$ (AcOEt/Cyclohexane 1:3, $v / v$ ) 0.36. HRMS (ESI) $m / z \quad[\mathrm{M}+\mathrm{H}]^{+}$calcd. for $\mathrm{C}_{23} \mathrm{H}_{21} \mathrm{~N}_{2} \mathrm{O}_{5}: \quad 405.1445 \mathrm{Da}$; found:
405.1446 Da. ${ }^{1} \mathrm{H}$ NMR $\delta 7.71(\mathrm{dd}, J=9.1 \mathrm{~Hz}, J=2.2 \mathrm{~Hz}, 2 \mathrm{H}), 7.31$ (m, 7H), 6.98-7.13 (m, 5H), $4.60(\mathrm{~s}, 2 \mathrm{H}), 4.54(\mathrm{~m}, 2 \mathrm{H}), 3.83(\mathrm{~m}, 2 \mathrm{H})$. ${ }^{13} \mathrm{C}$ NMR $\delta 157.14$ (s), 155.23 (s), 154.77 (s), 148.29 (s), 137.43 (s), 131.56 (s), $129.85(2 \times \mathrm{d}), 128.55(2 \times \mathrm{d}), 127.99$ (d), $127.79(2 \times \mathrm{d})$, 123.47 (d), $119.83(2 \times \mathrm{d}), 119.47(2 \times \mathrm{d}), 118.74(2 \times \mathrm{d}), 73.42(\mathrm{t})$, $70.56(t), 66.99(t)$.

4.1.1.2. 5-isoButyloxy-3-(4-phenoxyphenyl)-1,3,4-oxadiazol-2(3H)-one $(6 d=\mathbf{i B p P P O X})$. Prepared using Isobutyl chloroformate $4 \mathrm{~d}$ applying similar method as described above for $\mathbf{6 a}$. Analytical data for iBpPPOX: pale yellow oil (87\%). $R_{f}$ (AcOEt/Cyclohexane 1:3, $v / v$ ) 0.55 . HRMS (ESI) $m / z[\mathrm{M}+\mathrm{H}]^{+}$calcd. for $\mathrm{C}_{18} \mathrm{H}_{19} \mathrm{~N}_{2} \mathrm{O}_{4}$ : $327.1339 \mathrm{Da}$; found : 327.1342 Da. ${ }^{1} \mathrm{H}$ NMR $\delta 7.72(\mathrm{dd}, J=9.2 \mathrm{~Hz}, J=2.3 \mathrm{~Hz}, 2 \mathrm{H}), 7.30$ (m, 2H), 6.97-7.12 (m, 5H), $4.14(\mathrm{t}, J=6.6 \mathrm{~Hz}, 2 \mathrm{H}), 2.15(\mathrm{~m}, 1 \mathrm{H}), 1.0$ (d, 6H). ${ }^{13} \mathrm{C}$ NMR $\delta 157.17$ (s), $155.42(\mathrm{~s}), 154.67$ (s), 148.36 (s), $131.66(\mathrm{~s}), 129.83(2 \times \mathrm{d}), 123.42(\mathrm{~d}), 119.79(2 \times \mathrm{d}), 119.49(2 \times \mathrm{d})$, $118.69(2 \times d), 71.39(\mathrm{t}), 22.75(\mathrm{t}), 18.70(2 \times \mathrm{q})$.

Table 3

HPOX target proteins identified in $M . t b \mathrm{mc}^{2} 6230$ culture by LC-ESI-MS/MS analysis. ${ }^{\text {a }}$

\begin{tabular}{|c|c|c|c|c|c|c|}
\hline Protein name & Rv number & Mol. weight $[\mathrm{kDa}]$ & Essentiality & Location $^{\mathrm{b}}$ & Function & Functional category $^{\mathrm{c}}$ \\
\hline Cutinase Cfp21 & Rv1984c & 21.8 & & CF; CW; M & Lipase/esterase & $\mathrm{CW} / \mathrm{CP}$ \\
\hline Probable cutinase Cut2 & Rv2301 & 23.9 & & M, WCL, CF & hydrolase & $\mathrm{CW} / \mathrm{CP}$ \\
\hline Probable cutinase Cut3 & Rv3451 & 26.5 & & $\mathrm{M}, \mathrm{CF}$ & hydrolase & $\mathrm{CW} / \mathrm{CP}$ \\
\hline Lipase LipV & Rv3203 & 27.9 & & WCL & Lipase/esterase & $\mathrm{IM} / \mathrm{R}$ \\
\hline Non-heme bromoperoxidase BpoC & Rv0554 & 28.4 & & M & hydrolase & $\mathrm{V} / \mathrm{D} / \mathrm{A}$ \\
\hline Thioesterase TesA & Rv2928 & 29.2 & in vitro growth & M & Lipase/esterase & LM \\
\hline Monoglyceride lipase Rv0183 & Rv0183 & 30.3 & & M & Lipase/esterase & $\mathrm{IM} / \mathrm{R}$ \\
\hline Lipase LipH & Rv1399c & 33.9 & & M & Lipase/esterase & $\mathrm{IM} / \mathrm{R}$ \\
\hline Secreted antigen 85-B FbpB (Ag85B) & Rv1886c & 34.6 & & CF; CW; M & Lipase/esterase & LM \\
\hline Secreted antigen 85-A FbpA (Ag85A) & Rv3804c & 35.7 & in vitro & CF; CW; M & Lipase/esterase & LM \\
\hline Secreted antigen 85-C FbpC (Ag85C) & Rv0129c & 36.8 & & CF; CW & Lipase/esterase & LM \\
\hline Probable homoserine O-acetyltransferase MetA & Rv3341 & 39.8 & essential gene & $\mathrm{M}$ & Acyltransferase & $\mathrm{IM} / \mathrm{R}$ \\
\hline$\beta$-ketoacyl-ACP synthase KasA & Rv2245 & 43.3 & essential gene & CF; CW; M & Lipase/esterase & LM \\
\hline Hypothetical protein LH57_07490 & Rv1367c & 43.7 & & M & $\beta$-lactamase & $\mathrm{CW} / \mathrm{CP}$ \\
\hline Trigger factor Tig & Rv2462c & 50.6 & & M, WCL, CF & Protein export & $\mathrm{CW} / \mathrm{CP}$ \\
\hline Amidase AmiD & Rv3375 & 50.6 & & $\mathrm{CW} ; \mathrm{M}$ & Amidase & $\mathrm{IM} / \mathrm{R}$ \\
\hline Amidase AmiC & Rv2888c & 50.9 & & $\mathrm{CW} ; \mathrm{M}$ & Amidase & $\mathrm{IM} / \mathrm{R}$ \\
\hline Putative Carboxylesterase A CaeA & Rv2224c & 55.9 & Macrophage and in vitro & M, WCL, CF & Lipase/esterase & $\mathrm{CW} / \mathrm{CP}$ \\
\hline
\end{tabular}

a Only positive hits with a pFDR of $5 \%$ and a score threshold value $\geq 60$ were selected.

b CF: Culture filtrate; CW: Cell wall; M: Membrane fraction; WCL: Whole cell lysate.

c IM/R: Intermediary metabolism/respiration; CW/CP: cell wall/cell processes; LM: Lipid metabolism; V/D/A: Virulence, detoxification, adaptation. 


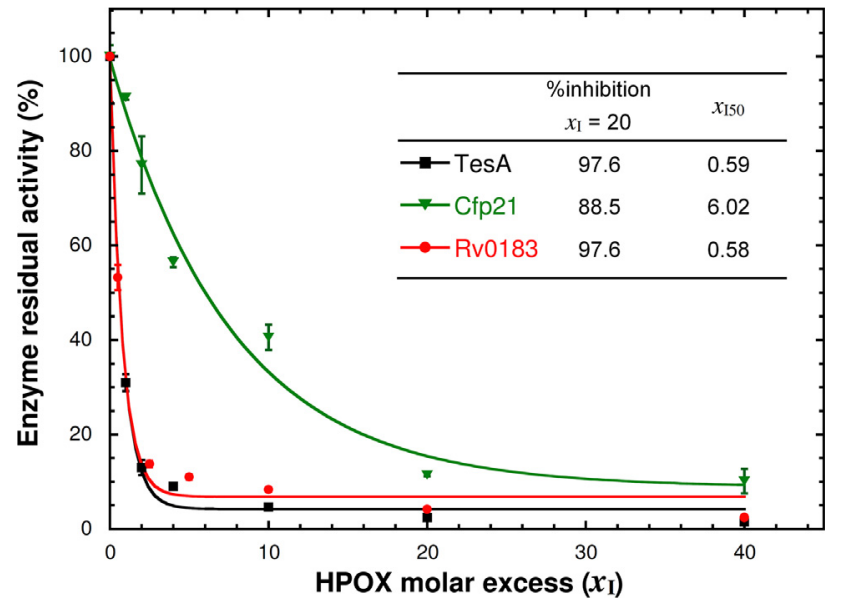

Fig. 5. HPOX efficiently impairs TesA, Cfp21 and Rv0183 activities in vitro. Variation of the residual activities of TesA, Cfp21 and Rv0183 as a function of increasing molar excess $\left(x_{\mathrm{I}}\right)$ of HPOX. Each enzyme was pre-incubated at various inhibitor molar excess $\left(x_{\mathrm{I}}\right)$ for $30 \mathrm{~min}$ at $25^{\circ} \mathrm{C}$. The inset displays the determined values of $x_{150}$ and the level of inhibition at $x_{\mathrm{I}}=20$. Kinetic assays were performed as described in Section 4. Results are expressed as mean values \pm SD of at least two independent assays.

4.1.1.3. 5-Hexyloxy-3-(4-phenoxyphenyl)-1,3,4-oxadiazol-2(3H)-one $(6 e=H p P P O X)$. Prepared using Hexyl chloroformate $4 \mathrm{e}$ applying similar method as described above for 6a. Analytical data for HpPPOX: yellow oil (85\%). $R_{f}$ (AcOEt/Cyclohexane 1:3, $\left.v / v\right) 0.95$. HRMS (ESI) $m / z[\mathrm{M}+\mathrm{H}]^{+}$calcd. for $\mathrm{C}_{20} \mathrm{H}_{23} \mathrm{~N}_{2} \mathrm{O}_{4}$ : $355.1652 \mathrm{Da}$; found : $355.1652 \mathrm{Da} .{ }^{1} \mathrm{H}$ NMR $\delta 7.72$ (dd, $\left.J=9.0 \mathrm{~Hz}, J=2.0 \mathrm{~Hz}, 2 \mathrm{H}\right), 7.30(\mathrm{~m}$, $2 \mathrm{H}), 6.97-7.12(\mathrm{~m}, 5 \mathrm{H}), 4.37(\mathrm{t}, J=6.6 \mathrm{~Hz}, 2 \mathrm{H}), 1.80(\mathrm{~m}, 2 \mathrm{H})$, $1.30-1.58(\mathrm{~m}, 6 \mathrm{H}), 0.90(\mathrm{t}, J=6.8 \mathrm{~Hz}, 3 \mathrm{H}) .{ }^{13} \mathrm{C}$ NMR $\delta 157.16(\mathrm{~s})$, 155.33 (s), 154.67 (s), 148.38 (s), 131.65 (s), 129.83 ( $2 \times$ d), 123.42 (d), $119.78(2 \times \mathrm{d}), 119.49(2 \times \mathrm{d}), 118.68(2 \times \mathrm{d}), 71.79(\mathrm{t}), 31.36$ (t), $28.35(t), 25.17(t), 22.50(t), 13.99(q)$.

\subsubsection{5-Benzyloxyethoxy-3-phenyl-1,3,4-oxadiazol-2(3H)-one}

$(7 a=B e P O X)$. Prepared using 2-benzyloxyethyl chloroformate $4 \mathbf{a}$ and phenylhydrazine hydrochloride $\mathbf{3}$ applying similar method as described above for 6a. Analytical data for BePOX: pale yellow oil (79\%). $R_{f}$ (AcOEt/Cyclohexane 1:3, v/v) 0.36. HRMS (ESI) $m / z[\mathrm{M}+\mathrm{H}]^{+}$calcd. for $\mathrm{C}_{7} \mathrm{H}_{17} \mathrm{~N}_{2} \mathrm{O}_{4}$ : $313.1183 \mathrm{Da}$; found : $313.1183 \mathrm{Da} .{ }^{1} \mathrm{H}$ NMR $\delta 7.75(\mathrm{~m}$, $2 \mathrm{H}), 7.18-7.73(\mathrm{~m}, 8 \mathrm{H}), 4.60(\mathrm{~s}, 2 \mathrm{H}), 4.54(\mathrm{~m}, 2 \mathrm{H}), 3.83(\mathrm{~m}, 2 \mathrm{H}) .{ }^{13} \mathrm{C}$ NMR $\delta 155.23$ (s), 148.23 (s), 137.44 (s), 136.17 (s), $129.12(2 \times \mathrm{d})$, $128.55(2 \times d), 127.98(d), 127.79(2 \times d), 125.56(d), 117.95(2 \times d)$, $73.41(t), 70.55(t), 66.98(t)$.

\subsubsection{5-isoButyloxy-3-phenyl-1,3,4-oxadiazol-2(3H)-one}

$(7 d=i B P O X)$. Prepared using Isobutyl chloroformate $4 \mathrm{~d}$ and phenylhydrazine hydrochloride $\mathbf{3}$ applying similar method as described above for 6a. Analytical data for iBPOX: white crystals (77\%). Mp: $76-77^{\circ} \mathrm{C} . R_{f}$ (AcOEt/Cyclohexane 1:3, v/v) 0.55. HRMS (ESI) $m / z[\mathrm{M}+\mathrm{Na}]^{+}$calcd. for $\mathrm{C}_{12} \mathrm{H}_{14} \mathrm{~N}_{2} \mathrm{O}_{3} \mathrm{Na}$ : $257.0897 \mathrm{Da}$; found : 257.0895 Da. ${ }^{1} \mathrm{H}$ NMR $\delta 7.80$ (m, 2H), 7.42 (m, 2H), 7.25 (m, 1H), 4.18 (d, $J=6.6 \mathrm{~Hz}, 2 \mathrm{H}), 1.85$ (m, 1H), 1.05 (d, 6H). ${ }^{13} \mathrm{C}$ NMR $\delta 155.63$ (s), 148.51 (s), 136.44 (s), $129.29(2 \times d), 125.67$ (d), $118.14(2 \times d)$, $77.57(\mathrm{t}), 27.94(\mathrm{~d}), 18.89(2 \times \mathrm{q})$.

\subsubsection{5-Hexyloxy-3-phenyl-1,3,4-oxadiazol-2(3H)-one}

$(7 \boldsymbol{e}=$ HPOX). Prepared using Hexyl chloroformate $4 \mathrm{e}$ and phenylhydrazine hydrochloride $\mathbf{3}$ applying similar method as described above for 6a. Analytical data for HPOX: white crystals (71\%). Mp: $34-35^{\circ} \mathrm{C} . R_{f}$ (AcOEt/Cyclohexane 1:3, $v / v$ ) 0.59. HRMS (ESI) $m / z[\mathrm{M}+\mathrm{H}]^{+}$calcd. for $\mathrm{C}_{14} \mathrm{H}_{19} \mathrm{~N}_{2} \mathrm{O}_{3}: 263.1390 \mathrm{Da}$; found : $263.1390 \mathrm{Da} . \quad{ }^{1} \mathrm{H} \quad \mathrm{NMR} \quad \delta \quad 7.80 \quad$ (ddd, $J=8.4 \mathrm{~Hz}, \quad J=2.3 \mathrm{~Hz}$,
$J=0.75 \mathrm{~Hz}, 2 \mathrm{H}), 7.42(\mathrm{dd}, J=7.6 \mathrm{~Hz}, J=1.7 \mathrm{~Hz}, 2 \mathrm{H}), 7.22(\mathrm{t}$, $J=7.4 \mathrm{~Hz}, 1 \mathrm{H}), 4.40(\mathrm{t}, J=6.6 \mathrm{~Hz}, 2 \mathrm{H}), 1.85(\mathrm{~m}, 2 \mathrm{H}), 1.33-1.49$ $(\mathrm{m}, 6 \mathrm{H}), 0.93(\mathrm{t}, 3 \mathrm{H}) .{ }^{13} \mathrm{C}$ NMR $\delta 155.54(\mathrm{~s}), 148.53(\mathrm{~s}), 136.45(\mathrm{~s})$, $129.30(2 \times d), 125.67(d), 118.13(2 \times d), 71.97(t), 31.45(t), 28.55$ $(\mathrm{t}), 25.36(\mathrm{t}), 22.68(\mathrm{t}), 14.17(\mathrm{q})$.

\subsection{Biological evaluation}

\subsubsection{Bacterial strains and growth condition}

M. marinum ATCC BAA-535/M, M. bovis BCG Pasteur 1173P2 and M. $t b \mathrm{mc}^{2} 6230$ (H37Rv $\triangle R D 1 \triangle$ panCD [28]) strains were routinely grown in Middlebrook 7H9 broth (BD Difco) supplemented with $0.2 \%$ glycerol, $0.05 \%$ Tween 80 (Sigma-Aldrich), 10\% oleic acid, albumin, dextrose, catalase (OADC enrichment; BD Difco) (7H9-S) and $24 \mu \mathrm{g} / \mathrm{mL}$ D-panthothenate (M. $\left.t b \mathrm{mc}^{2} 6230\right)$. For further intra and extracellular assays, $M$. $t b$ H37Rv expressing GFP [36] was grown for 14 days in 7H9S supplemented with $50 \mu \mathrm{g} / \mathrm{mL}$ hygromycin B (Euromedex). All cultures were kept at $37^{\circ} \mathrm{C}$ without shaking, except $M$. marinum which was grown at $32{ }^{\circ} \mathrm{C}$.

\subsubsection{Susceptibility testing on M. marinum, M. Bovis BCG and M. tb} $m c^{2} 6230$

The concentrations of compound leading to $50 \%$ of bacterial growth $\left(\mathrm{MIC}_{50}\right.$ ) were first determined using the resazurin microtiter assay (REMA) [29,30]. Briefly, log-phase bacteria were diluted to a cell density of $5 \times 10^{6}$ cells $/ \mathrm{mL}$ and $100 \mu \mathrm{L}$ of this inoculum was grown in a 96-well plate in the presence of serial dilutions of compounds. After $7-14$ days incubation, $20 \mu \mathrm{L}$ of a $0.025 \%(w / v)$ resazurin solution was added to each well $(200 \mu \mathrm{L})$ and incubation was continued until the appearance of a color change (from blue to pink) in the control well (bacteria without antibiotics). Fluorescence of the resazurin metabolite resorufin ( $\lambda_{\text {excitation }}, 530 \mathrm{~nm} ; \lambda_{\text {emission }}, 590 \mathrm{~nm}$ ) was then measured [30] and the concentration leading to $50 \%$ growth inhibition was defined as the MIC $_{50}$. See Supplementary Material for detailed protocol.

\subsubsection{High-content screening assay - extracellular assay}

A 14 days old culture of $M$. $t b$ H37Rv-GFP was washed twice with PBS and resuspended in 7H9 medium containing 10\% OADC, $0.5 \%$ glycerol, $0.05 \%$ Tween 80 and $50 \mu \mathrm{g} / \mathrm{mL}$ hygromycin B. Bacteria were seeded in 384 well plates $\left(7 \times 10^{5}\right.$ bacteria/mL) containing 2 -fold dilutions of the compounds in DMSO. The final volume of DMSO was kept under $0.3 \%$. Plates were incubated at $37^{\circ} \mathrm{C}, 5 \% \mathrm{CO}_{2}$ for 5 days. Bacterial fluorescence levels (RFU) were recorded using a fluorescent microplate reader (Victor X3, Perkin-Elmer). The $\mathrm{MIC}_{50}$ of all tested compounds were determined using ten-point dose-response curves. In each plate, negative control with $1 \%$ DMSO; and positive controls containing $1 \mu \mathrm{g} / \mathrm{mL}$ INH and RIF were also included.

\subsubsection{High-content screening assay in infected macrophages - intracellular assay}

The growth of $M$. $t b$ H37Rv-GFP strain in macrophages was monitored by automated fluorescence confocal microscope (Opera, PerkinElmer) as already described $[36,67]$. Briefly, bacteria were washed twice with PBS and resuspended in RPMI 1640 medium (Invitrogen) supplemented with $10 \%$ heat-inactivated fetal bovine serum (FBS, Invitrogen). Murine (Raw264.7) macrophages (American Type Culture Collection TIB-71) were infected at a multiplicity of infection (MOI) of 2:1 and incubated $2 \mathrm{~h}$ at $37^{\circ} \mathrm{C}$ in RPMI 1640 medium containing $10 \%$ FBS. Cells were then washed, treated with $50 \mu \mathrm{g} / \mathrm{mL}$ amikacin (Euromedex) for $1 \mathrm{~h}$ at $37^{\circ} \mathrm{C}$ to kill all extra-cellular bacteria, washed again and finally seeded in 384 -well plates $\left(5 \times 10^{5}\right.$ cells $\left./ \mathrm{mL}\right)$, containing 2fold dilutions of compounds in DMSO. The final volume of DMSO was kept under $0.3 \%$. Plates were incubated for 5 days at $37^{\circ} \mathrm{C}, 5 \% \mathrm{CO}_{2}$. Infected cells were stained for $30 \mathrm{~min}$ using Syto60 dye (Invitrogen) at a final concentration of $5 \mu \mathrm{M}$ before reading using fluorescence confocal microscope (20X water objective; GFP: $\lambda_{\text {ex }} 488 \mathrm{~nm}, \lambda_{\text {em }} 520 \mathrm{~nm}$; 
Syto60: $\left.\lambda_{\text {ex }} 640 \mathrm{~nm}, \lambda_{\text {em }} 690 \mathrm{~nm}\right)$. Dose-responses were fitted using Prism software (sigmoidal dose-response, variable slope model). The $\mathrm{MIC}_{50}$ was determined using ten-point dose-response curves as an average of the $\mathrm{MIC}_{50}$ of 4 parameters, the ratio of infected cells, the total area of bacteria, the cells number and the bacterial area per infected cell. In each plate, negative control with $1 \%$ DMSO (i.e., infected macrophages only); as well as positive controls containing $10 \mu \mathrm{g} / \mathrm{mL}$ INH, ETO and RIF were also included.

\subsection{HPOX target enzymes identification}

\subsubsection{Activity-based protein profiling (ABPP)}

Homogeneous bacterial suspension of $M$. $t b \mathrm{mc}^{2} 6230$ in 7H9-S was adjusted at an $\mathrm{OD}_{600}$ of 60 and then incubated with the selected HPOX inhibitor $\left(400 \mu \mathrm{M}\right.$ final concentration) or DMSO (control) at $37^{\circ} \mathrm{C}$ for 2-3 h. under gentle shaking at $75 \mathrm{rpm}$. Bacteria were then washed 3 times with PBS containing 0.05\% Tween 80, resuspended in PBS buffer at a $1: 1(w / v)$ ratio and then lysed by mechanical disruption on a BioSpec Beadbeater. Both HPOX-treated M. $t b \mathrm{mc}^{2} 6230$ and DMSOcontrol lysate samples $(750 \mu \mathrm{L}-0.75 \mathrm{mg}$ total proteins) were labeled with $2 \mu \mathrm{M}$ Desthiobiotin-FP probe for $90 \mathrm{~min}$ at room temperature. Samples were enriched for biotinylated proteins using Nanolink streptavidin magnetic beads $0.8 \mu \mathrm{m}$ (Solulink), according to the manufacturer's instructions. The resulting captured biotinylated proteins solution was mixed with $5 \mathrm{X}$ Laemmli reducing sample buffer, and heated at $95^{\circ} \mathrm{C}$ for $5 \mathrm{~min}$. The released denatured proteins were subjected to tryptic digestion, peptide extraction, and LC-MS/MS analysis as described below.

Alternatively, the HPOX-treated $M . t b \mathrm{mc}^{2} 6230$ and DMSO-control lysate samples ( $100 \mu \mathrm{L}-100 \mu \mathrm{g}$ total proteins) were incubated with $2 \mu \mathrm{M}$ ActivX TAMRA-FP probe (Thermo Fisher Scientific) for $90 \mathrm{~min}$ at room temperature and in absence of light. The reaction was stopped by adding $5 \times$ Laemmli reducing sample buffer and boiling at $95^{\circ} \mathrm{C}$ for $5 \mathrm{~min}$. The labeled proteins were further separated by SDS-PAGE electrophoresis. TAMRA fluorescence (TAMRA: $\lambda_{\text {ex }} 557 \mathrm{~nm}, \lambda_{\text {em }} 583 \mathrm{~nm}$ ) was detected using a ChemiDoc MP Imager (Bio-Rad). Detailed Materials and Methods is given in Supplementary Material.

\subsubsection{Protein identification and quantification}

Protein extract were loaded and stacked on a NuPAGE gel (Life Technologies). Stained bands were submitted to an in-gel trypsin digestion [68]. Peptides extracts were reconstituted with $0.1 \%$ trifluoroacetic acid in $4 \%$ acetonitrile and analyzed by liquid chromatography (LC)-tandem mass spectrometry (MS/MS) using an Orbitrap Fusion Lumos Tribrid Mass Spectrometer (Thermo Electron, Bremen, Germany) online with a an Ultimate 3000RSLC nano chromatography system (Thermo Fisher Scientific, Sunnyvale, CA). Protein identification and quantification were processed using the MaxQuant computational proteomics platform, version 1.5.3.8 [69] using a UniProt $M$. tuberculosis ATCC 25,618 database (date 2018.01; 2164 entries). The statistical analysis was done with Perseus program (version 1.5.6.0). Differential proteins were detected using a two-sample $t$-test at 0.01 and 0.05 permutation based FDR. The mass spectrometry proteomics data, including search results, have been deposited to the ProteomeXchange Consortium (www.proteomexchange.org) [70] via the PRIDE partner repository with the dataset identifier PXD010255. Detailed Materials and Methods is given in Supplementary Material.

\subsection{Inhibition assays on pure recombinant proteins}

The three lipolytic enzymes from $M$. $t b$, the thioesterase TesA, the monoacylglycerol lipase Rv0183, and the Cutinase-like protein Cfp21 were produced and purified as previously reported [48,55].

The lipase-inhibitor pre-incubation method was used to test, in aqueous medium and in the absence of substrate, the possible direct reactions between lipases and inhibitors as previously described
$[27,56,71]$. Briefly, an aliquot of each enzyme was pre-incubated at $25^{\circ} \mathrm{C}$ with HPOX at various inhibitor molar excess $\left(x_{\mathrm{I}}\right)$ ranging from 1 to 40 related to $1 \mathrm{~mol}$ of enzyme. A sample of the incubation medium was collected after $30 \mathrm{~min}$ incubation period and the residual enzyme activity was measured. The variation in the residual lipase activity allowed determination of the inhibitor molar excess which reduced the enzyme activity to $50 \%$ of its initial value $\left(x_{150}\right)[27,56,71]$. In each case, control experiments were performed in the absence of inhibitor. The respective enzymatic activity of TesA and Cfp21 were assessed using para-nitrophenyl ( $p \mathrm{NP}$ ) ester assay with $p$ NP caprylate ( $p$ NP-C8) as substrate, as described previously [23]. Rv0183 residual activity was determined using monoolein as substrate, as reported in [48,56]. Doseresponse curves were fitted in Kaleidagraph 4.2 Software (Synergy Software). Results are expressed as mean values \pm SD of at least two independent assays.

\section{Acknowledgements}

This work was supported by the CNRS and Aix-Marseille University. PCN was supported by a PhD Training program from the University of Science and Technology of Hanoi (837267E). Financial support to PB, VD and VL was provided by the European Community (ERC-STG INTRACELLTB no. 260901, MM4TB no. 260872, CycloNHit no. 608407), the Agence Nationale de la Recherche (ANR-10-EQPX-04-01, ANR-14-CE08-0017), the Feder (12001407 (D-AL) Equipex Imaginex BioMed), the Région Nord Pas de Calais (convention no. 12000080). Proteomics analysis was supported by the Institut Paoli-Calmettes and the Centre de Recherche en Cancérologie de Marseille. Proteomic analyses were done using the mass spectrometry facility of Marseille Proteomics (marseille-proteomique.univ-amu.fr) supported by IBISA (Infrastructures Biologie Santé et Agronomie), Plateforme Technologique Aix-Marseille, the Cancéropôle PACA, the ProvenceAlpes-Côte d'Azur Région, the Institut Paoli-Calmettes and the Centre de Recherche en Cancérologie de Marseille. VD is currently supported by the French Ministry of Foreign Affairs, the Korean Ministry of Science (MSIT) through the National Research Foundation of Korea (NRF, grant numbers 2017M3A9G6068246 and 2015R1C1A1A01053355) as well as the Gyeonggi province, Korea.

\section{Appendix A. Supplementary material}

Supplementary data associated with this article can be found, in the online version, at https://doi.org/10.1016/j.bioorg.2018.08.025.

\section{References}

[1] WHO, Global tuberculosis report, < http://www.who.int/tb/publications/global report/en/ > (2017).

[2] A.I. Zumla, S.H. Gillespie, M. Hoelscher, P.P. Philips, S.T. Cole, I. Abubakar, T.D. McHugh, M. Schito, M. Maeurer, A.J. Nunn, New antituberculosis drugs, regimens, and adjunct therapies: needs, advances, and future prospects, Lancet Infect. Dis. 14 (2014) 327-340.

[3] M. Pai, M.A. Behr, D. Dowdy, K. Dheda, M. Divangahi, C.C. Boehme, A. Ginsberg, S. Swaminathan, M. Spigelman, H. Getahun, D. Menzies, M. Raviglione, Tuberculosis, Nat. Rev. Dis. Primers 2 (2016) 16076.

[4] K. Andries, P. Verhasselt, J. Guillemont, H.W. Gohlmann, J.M. Neefs, H. Winkler, J. Van Gestel, P. Timmerman, M. Zhu, E. Lee, P. Williams, D. de Chaffoy, E. Huitric, S. Hoffner, E. Cambau, C. Truffot-Pernot, N. Lounis, V. Jarlier, A diarylquinoline drug active on the ATP synthase of Mycobacterium tuberculosis, Science 307 (2005) $223-227$.

[5] M. Matsumoto, H. Hashizume, T. Tomishige, M. Kawasaki, H. Tsubouchi, H. Sasaki, Y. Shimokawa, M. Komatsu, OPC-67683, a nitro-dihydro-imidazooxazole derivative with promising action against tuberculosis in vitro and in mice, PLoS Med. 3 (2006) e466.

[6] A.H. Diacon, R. Dawson, F. von Groote-Bidlingmaier, G. Symons, A. Venter, P.R. Donald, C. van Niekerk, D. Everitt, H. Winter, P. Becker, C.M. Mendel, M.K. Spigelman, 14-day bactericidal activity of PA-824, bedaquiline, pyrazinamide, and moxifloxacin combinations: a randomised trial, Lancet 380 (2012) 986-993.

[7] A.A. Velayati, M.R. Masjedi, P. Farnia, P. Tabarsi, J. Ghanavi, A.H. Ziazarifi, S.E. Hoffner, Emergence of new forms of totally drug-resistant tuberculosis bacilli: super extensively drug-resistant tuberculosis or totally drug-resistant strains in iran, 
Chest 136 (2009) 420-425.

[8] C.D. Acosta, A. Dadu, A. Ramsay, M. Dara, Drug-resistant tuberculosis in Eastern Europe: challenges and ways forward, Public Health Action 4 (2014) S3-S12.

[9] G. Gunther, Multidrug-resistant and extensively drug-resistant tuberculosis: a review of current concepts and future challenges, Clin. Med. 14 (2014) 279-285.

[10] G. Gunther, F. van Leth, N. Altet, M. Dedicoat, R. Duarte, G. Gualano, H. Kunst, I. Muylle, V. Spinu, S. Tiberi, P. Viiklepp, C. Lange, Beyond multidrug-resistant tuberculosis in Europe: a TBNET study, Int. J. Tuberc. Lung Dis. 19 (2015) 1524-1527.

[11] J.A. Aeschlimann, A. Stempel. Heterocyclic Antituberculous Compounds, US2665279, 1954

[12] A.E. Wilder Smith, The action of phosgene on acid hydrazides to give 1, 3, 4-oxdiazolones of interest in the treatment of tuberculosis, Science 119 (1954) 514

[13] A.E. Wilder Smith, H. Brodhage, Biological spectrum of some new tuberculostatic 1,3,4-oxadiazolones with special reference to cross-resistance and rates of emergence of resistance, Nature 192 (1961) 1195.

[14] A.E. Wilder Smith, H. Brodhage, G. Haukenes, Some tuberculostatic 1,3,4-oxadiazolones(-5) and 1,3,4-oxadiazolthiones(-5). II: biological spectrum in vitro and activity in vivo in relation to resistance emergence, Arzneimittelforschung 12 (1962) 275-280.

[15] A.E. Wilder Smith, Some Recently Synthesised Tuberculostatic 4-Substituted Oxadiazolones and Oxadiazol-Thiones, VI, Arzneimittel-Forschung, 16 (1966) $1034-1038$

[16] M.G. Mamolo, D. Zampieri, L. Vio, M. Fermeglia, M. Ferrone, S. Pricl, G. Scialino, E. Banfi, Antimycobacterial activity of new 3-substituted 5-(pyridin-4-yl)-3H-1,3,4oxadiazol-2-one and 2-thione derivatives. Preliminary molecular modeling investigations, Bioorg. Med. Chem. 13 (2005) 3797-3809.

[17] D. Zampieri, M.G. Mamolo, E. Laurini, M. Fermeglia, P. Posocco, S. Pricl, E. Banfi, G. Scialino, L. Vio, Antimycobacterial activity of new 3,5-disubstituted 1,3,4-oxadiazol-2(3H)-one derivatives. Molecular modeling investigations, Bioorg. Med. Chem. 17 (2009) 4693-4707.

[18] A. Bellamine, A.T. Mangla, W.D. Nes, M.R. Waterman, Characterization and catalytic properties of the sterol 14alpha-demethylase from Mycobacterium tuberculosis, Proc. Natl. Acad. Sci. USA 96 (1999) 8937-8942.

[19] D.J. Sheehan, C.A. Hitchcock, C.M. Sibley, Current and emerging azole antifunga agents, Clin. Microbiol. Rev. 12 (1999) 40-79.

[20] K.J. McLean, A.J. Dunford, R. Neeli, M.D. Driscoll, A.W. Munro, Structure, function and drug targeting in Mycobacterium tuberculosis cytochrome P450 systems, Arch. Biochem. Biophys. 464 (2007) 228-240.

[21] Y. Ben Ali, H. Chahinian, S. Petry, G. Muller, R. Lebrun, R. Verger, F. Carrière, L. Mandrich, M. Rossi, G. Manco, L. Sarda, A. Abousalham, Use of an inhibitor to identify members of the hormone-sensitive lipase family, Biochemistry 45 (2006) 14183-14191.

[22] Y. Ben Ali, R. Verger, F. Carrière, S. Petry, G. Muller, A. Abousalham, The molecular mechanism of human hormone-sensitive lipase inhibition by substituted 3-phenyl5-alkoxy-1,3,4-oxadiazol-2-ones, Biochimie 94 (2012) 137-145.

[23] V. Delorme, S.V. Diomandé, L. Dedieu, J.-F. Cavalier, F. Carrière, L. Kremer, J. Leclaire, F. Fotiadu, S. Canaan, MmPPOX Inhibits Mycobacterium tuberculosis lipolytic enzymes belonging to the hormone-sensitive lipase family and alters mycobacterial growth, PLoS One 7 (2012) e46493.

[24] B. Borgström, Mode of action of tetrahydrolipstatin: a derivative of the naturally occuring lipase inhibitor lipstatin, Biochim. Biophys. Acta 962 (1988) 308-316.

[25] P. Hadváry, W. Sidler, W. Meister, W. Vetter, H. Wolfer, The lipase inhibitor tetrahydrolipstatin binds covalently to the putative active site serine of pancreatic lipase, J. Biol. Chem. 266 (1991) 2021-2027.

[26] A. Bénarouche, V. Point, F. Carrière, J.-F. Cavalier, Using the reversible inhibition of gastric lipase by Orlistat for investigating simultaneously lipase adsorption and substrate hydrolysis at the lipid-water interface, Biochimie 101 (2014) 221-231.

[27] V. Point, A. Bénarouche, J. Zarillo, A. Guy, R. Magnez, L. Fonseca, B. Raux, J. Leclaire, G. Buono, F. Fotiadu, T. Durand, F. Carrière, C. Vaysse, L. Couëdelo, J.F. Cavalier, Slowing down fat digestion and absorption by an oxadiazolone inhibitor targeting selectively gastric lipolysis, Eur. J. Med. Chem. 123 (2016) 834-848.

[28] V.K. Sambandamurthy, S.C. Derrick, T. Hsu, B. Chen, M.H. Larsen, K.V. Jalapathy, M. Chen, J. Kim, S.A. Porcelli, J. Chan, S.L. Morris, W.R. Jacobs Jr., Mycobacterium tuberculosis DeltaRD1 DeltapanCD: a safe and limited replicating mutant strain that protects immunocompetent and immunocompromised mice against experimental tuberculosis, Vaccine 24 (2006) 6309-6320.

[29] J.C. Palomino, A. Martin, M. Camacho, H. Guerra, J. Swings, F. Portaels, Resazurin microtiter assay plate: simple and inexpensive method for detection of drug resistance in Mycobacterium tuberculosis, Antimicrob. Agents Chemother. 46 (2002) 2720-2722.

[30] J. Rybniker, A. Vocat, C. Sala, P. Busso, F. Pojer, A. Benjak, S.T. Cole, Lansoprazole is an antituberculous prodrug targeting cytochrome bc1, Nat. Commun. 6 (2015) 7659.

[31] P.C. Nguyen, V. Delorme, A. Bénarouche, B.P. Martin, R. Paudel, G.R. Gnawali, A. Madani, R. Puppo, V. Landry, L. Kremer, P. Brodin, C.D. Spilling, J.-F. Cavalier, S. Canaan, Cyclipostins and Cyclophostin analogs as promising compounds in the fight against tuberculosis, Sci. Rep. 7 (2017) 11751.

[32] P.C. Nguyen, A. Madani, P. Santucci, B.P. Martin, R.R. Paudel, S. Delattre, J.L. Herrmann, C.D. Spilling, L. Kremer, S. Canaan, J.-F. Cavalier, Cyclophostin and Cyclipostins analogs, new promising molecules to treat mycobacterial-related diseases, Int. J. Antimicrob. Agents 51 (2018) 651-654.

[33] R.J. Wallace Jr., D.R. Nash, L.C. Steele, V. Steingrube, Susceptibility testing of slowly growing mycobacteria by a microdilution MIC method with 7 H9 broth, J. Clin. Microbiol. 24 (1986) 976-981.

[34] A. Aubry, V. Jarlier, S. Escolano, C. Truffot-Pernot, E. Cambau, Antibiotic susceptibility pattern of Mycobacterium marinum, Antimicrob. Agents Chemother. 44 (2000) 3133-3136.

[35] N. Ritz, M. Tebruegge, T.G. Connell, A. Sievers, R. Robins-Browne, N. Curtis, Susceptibility of Mycobacterium bovis BCG vaccine strains to antituberculous antibiotics, Antimicrob. Agents Chemother. 53 (2009) 316-318.

[36] T. Christophe, M. Jackson, H.K. Jeon, D. Fenistein, M. Contreras-Dominguez, J. Kim, A. Genovesio, J.P. Carralot, F. Ewann, E.H. Kim, S.Y. Lee, S. Kang, M.J. Seo, E.J. Park, H. Skovierova, H. Pham, G. Riccardi, J.Y. Nam, L. Marsollier, M. Kempf, M.L. Joly-Guillou, T. Oh, W.K. Shin, Z. No, U. Nehrbass, R. Brosch, S.T. Cole, P. Brodin, High content screening identifies decaprenyl-phosphoribose 2' epimerase as a target for intracellular antimycobacterial inhibitors, PLoS Pathog. 5 (2009) e1000645.

[37] T. Christophe, F. Ewann, H.K. Jeon, J. Cechetto, P. Brodin, High-content imaging of Mycobacterium tuberculosis-infected macrophages: an in vitro model for tuberculosis drug discovery, Future Med. Chem. 2 (2010) 1283-1293.

[38] P. Brodin, T. Christophe, High-content screening in infectious diseases, Curr. Opin. Chem. Biol. 15 (2011) 534-539.

[39] M. Flipo, M. Desroses, N. Lecat-Guillet, B. Dirie, X. Carette, F. Leroux, C. Piveteau, F. Demirkaya, Z. Lens, P. Rucktooa, V. Villeret, T. Christophe, H.K. Jeon, C. Locht, P. Brodin, B. Deprez, A.R. Baulard, N. Willand, Ethionamide boosters: synthesis, biological activity, and structure-activity relationships of a series of 1,2,4-oxadiazole EthR inhibitors, J. Med. Chem. 54 (2011) 2994-3010.

[40] J. Neres, R.C. Hartkoorn, L.R. Chiarelli, R. Gadupudi, M.R. Pasca, G. Mori, A. Venturelli, S. Savina, V. Makarov, G.S. Kolly, E. Molteni, C. Binda, N. Dhar S. Ferrari, P. Brodin, V. Delorme, V. Landry, A.L. de Jesus Lopes, D. Ribeiro, P. Farina, F. Saxena, A. Pojer, R. Carta, A. Luciani, G. Porta, E. De Zanoni, M.P. Rossi, G. Costi, S.T. Cole Riccardi, 2-Carboxyquinoxalines Kill Mycobacterium tuberculosis through Noncovalent Inhibition of DprE1, ACS Chem. Biol. 10 (2015) 705-714.

[41] M.S. Ravindran, S.P. Rao, X. Cheng, A. Shukla, A. Cazenave-Gassiot, S.Q. Yao, M.R. Wenk, Targeting lipid esterases in mycobacteria grown under different physiological conditions using activity-based profiling with tetrahydrolipstatin (THL), Mol. Cell. Proteomics 13 (2014) 435-448.

[42] J. Lehmann, J. Vomacka, K. Esser, M. Nodwell, K. Kolbe, P. Ramer, U. Protzer, N. Reiling, S.A. Sieber, Human lysosomal acid lipase inhibitor lalistat impairs Mycobacterium tuberculosis growth by targeting bacterial hydrolases, MedChemComm 7 (2016) 1797-1801.

[43] C. Ortega, L.N. Anderson, A. Frando, N.C. Sadler, R.W. Brown, R.D. Smith, A.T. Wright, C. Grundner, Systematic survey of serine hydrolase activity in Mycobacterium tuberculosis defines changes associated with persistence, Cell Chem. Biol. 23 (2016) 290-298.

[44] K.R. Tallman, S.R. Levine, K.E. Beatty, Small molecule probes reveal esterases with persistent activity in dormant and reactivating Mycobacterium tuberculosis, ACS Infect. Dis. 2 (2016) 936-944.

[45] S. Canaan, D. Maurin, H. Chahinian, B. Pouilly, C. Durousseau, F. Frassinetti, L. Scappuccini-Calvo, C. Cambillau, Y. Bourne, Expression and characterization of the protein Rv1399c from Mycobacterium tuberculosis. A novel carboxyl esterase structurally related to the HSL family, Eur. J. Biochem. 271 (2004) 3953-3961.

[46] G. Singh, S. Arya, D. Narang, D. Jadeja, U.D. Gupta, K. Singh, J. Kaur, Characterization of an acid inducible lipase Rv3203 from Mycobacterium tuberculosis H37Rv, Mol. Biol. Rep. 41 (2014) 285-296.

[47] N.P. West, F.M. Chow, E.J. Randall, J. Wu, J. Chen, J.M. Ribeiro, W.J. Britton, Cutinase-like proteins of Mycobacterium tuberculosis: characterization of their variable enzymatic functions and active site identification, FASEB J. 23 (2009) 1694-1704.

[48] K. Côtes, R. Dhouib, I. Douchet, H. Chahinian, A. De Caro, F. Carriere, S. Canaan, Characterization of an exported monoglyceride lipase from Mycobacterium tuberculosis possibly involved in the metabolism of host cell membrane lipids, Biochem J. 408 (2007) 417-427.

[49] J.C. Sacchettini, D.R. Ronning, The mycobacterial antigens 85 complex-from structure to function: response, Trends Microbiol. 8 (2000) 441.

[50] J.T. Belisle, V.D. Vissa, T. Sievert, K. Takayama, P.J. Brennan, G.S. Besra, Role of the major antigen of Mycobacterium tuberculosis in cell wall biogenesis, Science 276 (1997) 1420-1422.

[51] L. Alibaud, Y. Rombouts, X. Trivelli, A. Burguiere, S.L. Cirillo, J.D. Cirillo, J.F. Dubremetz, Y. Guerardel, G. Lutfalla, L. Kremer, A Mycobacterium marinum TesA mutant defective for major cell wall-associated lipids is highly attenuated in Dictyostelium discoideum and zebrafish embryos, Mol. Microbiol. 80 (2011) 919-934.

[52] S. Lun, W.R. Bishai, Characterization of a novel cell wall-anchored protein with carboxylesterase activity required for virulence in Mycobacterium tuberculosis, J. Biol. Chem. 282 (2007) 18348-18356.

[53] R.A. Slayden, C.E. Barry 3rd, The role of KasA and KasB in the biosynthesis of meromycolic acids and isoniazid resistance in Mycobacterium tuberculosis, Tuberculosis (Edinb) 82 (2002) 149-160.

[54] G. Johnson, The alpha/beta hydrolase fold proteins of Mycobacterium tuberculosis, with reference to their contribution to virulence, Curr. Protein Pept. Sci. 18 (2017) $190-210$.

[55] M. Schué, D. Maurin, R. Dhouib, J.C. Bakala N'Goma, V. Delorme, G. Lambeau, F. Carriere, S. Canaan, Two cutinase-like proteins secreted by Mycobacterium tuberculosis show very different lipolytic activities reflecting their physiological function, FASEB J. 24 (2010) 1893-1903.

[56] V. Point, R.K. Malla, S. Diomande, B.P. Martin, V. Delorme, F. Carriere, S. Canaan, N.P. Rath, C.D. Spilling, J.-F. Cavalier, Synthesis and kinetic evaluation of Cyclophostin and Cyclipostins phosphonate analogs as selective and potent in hibitors of microbial lipases, J. Med. Chem. 55 (2012) 10204-10219. 
[57] C. Rens, F. Laval, M. Daffe, O. Denis, R. Frita, A. Baulard, R. Wattiez, P. Lefevre, V. Fontaine, Effects of lipid-lowering drugs on vancomycin susceptibility of mycobacteria, Antimicrob. Agents Chemother. 60 (2016) 6193-6199.

[58] B. Brust, M. Lecoufle, E. Tuaillon, L. Dedieu, S. Canaan, V. Valverde, L. Kremer, Mycobacterium tuberculosis lipolytic enzymes as potential biomarkers for the diagnosis of active tuberculosis, PLoS One 6 (2011) e25078.

[59] L. Dedieu, C. Serveau-Avesque, L. Kremer, S. Canaan, Mycobacterial lipolytic enzymes: a gold mine for tuberculosis research, Biochimie 95 (2013) 66-73.

[60] C. Deb, J. Daniel, T. Sirakova, B. Abomoelak, V. Dubey, P. Kolattukudy, A novel lipase belonging to the hormone-sensitive lipase family induced under starvation to utilize stored triacylglycerol in Mycobacterium tuberculosis, J. Biol. Chem. 281 (2006) 3866-3875.

[61] R. Dhouib, A. Ducret, P. Hubert, F. Carriere, S. Dukan, S. Canaan, Watching intracellular lipolysis in mycobacteria using time lapse fluorescence microscopy, Biochim. Biophys. Acta 2011 (1811) 234-241.

[62] O. Neyrolles, R. Hernández-Pando, F. Pietri-Rouxel, P. Fornès, L. Tailleux, J.A. Payán, E. Pivert, Y. Bordat, D. Aguilar, M.C. Prévost, Is adipose tissue a place for Mycobacterium tuberculosis persistence? PLoS One 1 (2006) e43.

[63] P. Peyron, J. Vaubourgeix, Y. Poquet, F. Levillain, C. Botanch, F. Bardou, M. Daffe, J.F. Emile, B. Marchou, P.J. Cardona, C. de Chastellier, F. Altare, Foamy macrophages from tuberculous patients' granulomas constitute a nutrient-rich reservoir for M. tuberculosis persistence, PLoS Pathog. 4 (2008) e1000204.

[64] P. Santucci, F. Bouzid, N. Smichi, I. Poncin, L. Kremer, C. De Chastellier, M. Drancourt, S. Canaan, Experimental models of foamy macrophages and approaches for dissecting the mechanisms of lipid accumulation and consumption during dormancy and reactivation of tuberculosis, Front. Cell. Infect. Microbiol. 6 (2016) 122.

[65] P. Santucci, S. Diomandé, I. Poncin, L. Alibaud, A. Viljoen, L. Kremer, C. de Chastellier, S. Canaan, Delineating the physiological roles of the PE and catalytic domain of LipY in lipid consumption in mycobacteria-infected foamy macrophages, Infect. Immun. (2018), https://doi.org/10.1128/iai.00394-00318.

[66] V. Point, K.V.P. Pavan Kumar, S. Marc, V. Delorme, G. Parsiegla, S. Amara, F. Carrière, G. Buono, F. Fotiadu, S. Canaan, J. Leclaire, J.-F. Cavalier, Analysis of the discriminative inhibition of mammalian digestive lipases by 3-phenyl substituted 1,3,4-oxadiazol-2(3H)-ones, Eur. J. Med. Chem. 58 (2012) 452-463.

[67] K. Pethe, P. Bifani, J. Jang, S. Kang, S. Park, S. Ahn, J. Jiricek, J. Jung, H.K. Jeon, J. Cechetto, T. Christophe, H. Lee, M. Kempf, M. Jackson, A.J. Lenaerts, H. Pham, V. Jones, M.J. Seo, Y.M. Kim, M. Seo, J.J. Seo, D. Park, Y. Ko, I. Choi, R. Kim,

S.Y. Kim, S. Lim, S.-A. Yim, J. Nam, H. Kang, H. Kwon, C.-T. Oh, Y. Cho, Y. Jang, J. Kim, A. Chua, B.H. Tan, M.B. Nanjundappa, S.P.S. Rao, W.S. Barnes, R. Wintjens, J.R. Walker, S. Alonso, S. Lee, J. Kim, S. Oh, T. Oh, U. Nehrbass, S.-J. Han, Z. No, J. Lee, P. Brodin, S.-N. Cho, K. Nam, J. Kim, Discovery of Q203, a potent clinical candidate for the treatment of tuberculosis, Nat. Med. 19 (2013) 1157-1160.

[68] A. Shevchenko, M. Wilm, O. Vorm, M. Mann, Mass spectrometric sequencing of proteins silver-stained polyacrylamide gels, Anal Chem. 68 (1996) 850-858.

[69] J. Cox, M. Mann, MaxQuant enables high peptide identification rates, individualized p.p.b.-range mass accuracies and proteome-wide protein quantification, Nat. Biotechnol. 26 (2008) 1367-1372.

[70] J.A. Vizcaino, E.W. Deutsch, R. Wang, A. Csordas, F. Reisinger, D. Rios, J.A. Dianes, Z. Sun, T. Farrah, N. Bandeira, P.A. Binz, I. Xenarios, M. Eisenacher, G. Mayer, L. Gatto, A. Campos, R.J. Chalkley, H.J. Kraus, J.P. Albar, S. Martinez-Bartolome, R. Apweiler, G.S. Omenn, L. Martens, A.R. Jones, H. Hermjakob, ProteomeXchange provides globally coordinated proteomics data submission and dissemination, Nat. Biotechnol. 32 (2014) 223-226.

[71] A. Viljoen, M. Richard, P.C. Nguyen, P. Fourquet, L. Camoin, R.R. Paudal, G.R. Gnawali, C.D. Spilling, J.-F. Cavalier, S. Canaan, M. Blaise, L. Kremer, Cyclipostins and Cyclophostin analogs inhibit the antigen 85C from Mycobacterium tuberculosis both in vitro and in vivo, J. Biol. Chem. 293 (2018) 2755-2769. 